\title{
Inter-annual variations of 6.5-day planetary waves and their relations with QBO
}

\author{
YingYing Huang ${ }^{1,2,3 *}$, Jun Cui ${ }^{4,5}$, HuiJun $\mathrm{Li}^{6}$, and ChongYin $\mathrm{Li}^{7}$ \\ ${ }^{1}$ National Astronomical Observatories, Chinese Academy of Sciences, Beijing 100101, China; \\ ${ }^{2}$ State Key Laboratory of Space Weather, Chinese Academy of Sciences, Beijing 100101, China; \\ ${ }^{3}$ CAS Key Laboratory of Lunar and Deep Space Exploration, National Astronomical Observatories, Chinese Academy of Sciences, Beijing 100101, China; \\ ${ }^{4}$ Planetary Environmental and Astrobiological Research Laboratory (PEARL), School of Atmospheric Sciences, Sun Yat-sen University, Zhuhai Guangdong \\ 519082, China; \\ ${ }^{5}$ School of Atmospheric Sciences, Sun Yat-Sen University, Zhuhai Guangdong 519082, China; \\ ${ }^{6}$ College of Astronautics, Nanjing University of Aeronautics and Astronautics, Nanjing 210016, China; \\ ${ }^{7}$ LASG, Institute of Atmospheric Physics, Chinese Academy of Sciences, Beijing 100029, China
}

Key Points:

- Main periods in long-term variations of 6.5DWs are determined.

- Long-term inter-annual variations of 6.5DWs in both hemispheres show 'QBO-like' signals.

- Correlation coefficients between 6.5DWs and QBO phases demonstrate hemispheric asymmetry.

Citation: Huang, Y. Y., Cui, J., Li, H. J., and Li, C. Y. (2022). Inter-annual variations of 6.5-day planetary waves and their relations with QBO. Earth Planet. Phys., 6(2), 135-148. http://doi.org/10.26464/epp2022005

\begin{abstract}
This paper studies inter-annual variations of 6.5-Day Waves (6.5DWs) observed at altitudes $20-110 \mathrm{~km}$ between $52^{\circ} \mathrm{S}-52^{\circ} \mathrm{N}$ latitudes during March 2002-January 2021, and how these variations were related to the equatorial stratospheric Quasi-Biennial Oscillation (QBO). Temperature amplitudes of the 6.5DWs are calculated based on SABER/TIMED observations. QBO zonal winds are obtained from an ERA5 reanalysis dataset. QBO phases are derived using an Empirical Orthogonal Functions (EOF) method. Wavelet analysis of the observed 6.5DW variations demonstrates obvious spectral maximums around $28-38$ months at $32^{\circ} \mathrm{N}-52^{\circ} \mathrm{N}$, and around 26-30 months at $32^{\circ} \mathrm{S}-52^{\circ} \mathrm{S}$. In the Northern Hemisphere, peak periods lengthened poleward; in the Southern Hemisphere, however, they were unchanged with latitude. Residual 6.5DWs amplitudes have been determined by removing composite amplitudes from 6.5DWs amplitudes. Comparisons between QBO and monthly maximum residual 6.5DWs amplitudes ( $A_{\text {Mmax }}$ ) show clear correlations between the QBO and 6.5DWs in both hemispheres, but the observed relationship is stronger in the $\mathrm{NH}$. When $A_{\mathrm{Mmax}}$ were large in the $\mathrm{NH}$, the mean QBO profile was easterly at all levels from 70 to $5 \mathrm{hPa}$; when the $A_{\mathrm{Mmax}}$ were weak, the mean QBO wind was weak westerly below $30 \mathrm{hPa}$. Linear Pearson correlation coefficients between QBO phases and $A_{\mathrm{Mmax}}$ show large positive values at 60-110 km between $20^{\circ} \mathrm{N}-52^{\circ} \mathrm{N}$ in April and around $64 \mathrm{~km}$ at $24^{\circ} \mathrm{S}$ in February, and large negative values from 80 to $110 \mathrm{~km}$ between $20^{\circ} \mathrm{N}-50^{\circ} \mathrm{N}$ in August and at $96-106 \mathrm{~km}$ between $20^{\circ} \mathrm{S}-44^{\circ} \mathrm{S}$ in February. These results indicate quantitative correlations between QBO and 6.5DWs and provide credible evidences for further studies of QBO modulations on long-term variations of 6.5DWs.
\end{abstract}

Keywords: planetary wave; quasi-biennial osillations; wave-flow interactions; satellite observation

\section{Introduction}

Six-and-a half-Day Waves (6.5DWs) are westward propagating planetary-scale waves in Earth's atmosphere from the stratosphere to the lower thermosphere, with period 6-7 days and zonal wavenumber 1 (Wu DL et al., 1994; Meyer and Forbes, 1997; Talaat et al., 2001; Kishore et al., 2004; Liu HL et al., 2004; Lima et al., 2005; Jiang G et al., 2008a, b; Wang JY et al., 2020). Though the exact periods of $6.5 \mathrm{DWs}$ vary from 5 to 7 days, $6.5 \mathrm{DWs}$ with different

Correspondence to: Y. Y. Huang, huangyy@bao.ac.cn

Received 19 JUL 2021; Accepted 04 OCT 2021.

Accepted article online 25 JAN 2022.

(C) 2022 by Earth and Planetary Physics. periods are very similar in latitude distribution and patterns of temporal variation (Wu DL et al., 1994; Miyoshi and Hirooka, 2003; Merkel et al., 2003; Riggin et al., 2006; von Savigny et al., 2007; Day et al., 2012; Merzlyakov et al., 2013; Pancheva et al., 2018). Therefore, it is reasonable to consider the 6.5DWs studied here as entirely comparable to the 5-day waves (5DWs), 6-day waves (6DWs) or 5-7-day waves mentioned in those studies. The 6.5DWs' amplitudes in temperature and horizontal wind are found dominant at three separate vertical layers: around the stratosphere (40-50 km), the mesosphere $(80-90 \mathrm{~km})$, and the lower thermosphere (100110 km) (Talaat et al., 2001; Liu HL et al., 2004; Jiang G et al., 2008a; Huang YY et al., 2017), respectively. Both ground and satellite observations have demonstrated convincingly that in both hemi- 
spheres the 6.5DWs' annual maximums usually emerge during equinoctial seasons in the mesosphere and the lower thermosphere (MLT) (Talaat et al., 2001; Liu HL et al., 2004; Jiang G et al., 2008a; b; Huang YY et al., 2017; Wang JY et al., 2020) and during winters in the stratosphere (Liu HL et al., 2004; Riggin et al., 2006; Huang YY et al., 2017).

Inter-annual trends of 6.5DWs over decades have been much less discussed than their seasonal variations during single years because long-term observations have been lacking. However, based on limited observational data, preliminary results of $6.5 \mathrm{DWs}^{\prime}$ longer-term inter-annual variations have been obtained. Based on observations of no longer than five years, 6.5DWs in MLT zonal wind at low latitudes in both hemispheres have been found to be more intense during westward (easterly) phase years of the quasibiennial oscillation (QBO) (Kishore et al., 2004; Lima et al., 2005). Similar results have been obtained also for 6.5DWs in fields of temperature and geopotential heights in both hemispheres, based on 2-6 decades' observations (Pancheva et al., 2010, 2018; Merzlyakov et al., 2013) and use of the NCEP reanalysis dataset (Miyoshi and Hirooka, 2003). It has also been suggested that longterm variations of 6.5DWs may be affected by solar cycles (SC) and sudden stratospheric warming (SSW) (Pancheva et al., 2010).

The QBO was first discovered by Reed et al. (1961). It dominates long-term dynamics in the equatorial lower stratosphere ( 16$50 \mathrm{~km}$ ) (Baldwin et al., 2001), demonstrating an alternated westerlies and easterlies with a roughly 2-year period ( 28 months) on average. Monthly averaged QBO zonal-mean zonal winds in both directions propagate downwards at a speed of $\sim 1 \mathrm{~km} /$ month and dissipate at the base of the stratosphere. Extensive geodynamical studies have confirmed that the combined forces of tropical tropospheric waves play the dominant roles in QBO generation, including Rossby waves, mixed Rossby-gravity waves, and Kelvin waves (Baldwin et al., 2001; Kim and Chun, 2015, and references therein).

Evaluating potential QBO impacts on global atmospheric dynamical systems is one of the most important questions in QBO studies (Boville, 1984; Balachandran and Rind, 1995; Gray et al., 2001; de Wit et al., 2016; Laskar et al., 2016). Although located in the tropical lower stratosphere, the QBO has a profound impact on global atmospheric circulation (Holton and Tan HC, 1980; Garfinkel et al., 2012; Rao J et al., 2019), on particle transportation (e.g. Ozone, nitrogen dioxide (Zawodny and McCormick, 1991)), and on water vapor (Tao MC et al., 2015). A commonly accepted mechanism of QBO modulations on extratropical atmospheric fields is called the 'Holton-Tan effect' (referred to as 'HT effect' in the rest of this paper), first put forward by Holton and Tan HC (1980). It points out that the equatorial QBO can shift the latitude of critical lines and contribute to the formation of an extratropical $50 \mathrm{mb}(1 \mathrm{mb}=1 \mathrm{hPa}) \mathrm{QBO}$. By modulating the atmospheric environments through which planetary waves propagate, the QBO can further influence inter-annual variations of wave activities at the extratropical MLT region, and even the waves' interhemispheric coupling processes (de Wit et al., 2016). Uncovering these geodynamical processes is necessary to better understand operation processes of the global atmospheric dynamical system. However, quantitative relations between the $\mathrm{QBO}$ and atmospheric wave parameters have not yet been completely described.

Recently, QBO-like modulations have been detected in inter-annual variations of different wave parameters in MLT regions, e.g., vertical flux of both zonal and meridional momentum of gravity waves (GWs) (de Wit et al., 2016), amplitudes of semi-diurnal migrating tides (Laskar et al., 2016), and planetary waves (PWs) (Miyoshi and Hirooka, 2003; Kishore et al., 2004; Lima et al., 2005; Li T et al., 2008; Pancheva et al., 2010; Merzlyakov et al., 2013), etc.

For most studies of correlations between the QBO and atmospheric dynamics, QBO phases are determined by zonal wind directions at a single level over the equatorial region; this altitude is usually chosen to be characterized by either $30 \mathrm{hPa}$ or $50 \mathrm{hPa}$ atmospheric pressure (Merzlyakov et al., 2013, 2015; de Wit et al., 2016; Laskar et al., 2016). Focus on wind directions at a single altitude brings out ambiguity (Baldwin and Dunkerton, 1989; Anstey and Shepherd, 2014; Solomon et al., 2014): on one hand, altitudes are chosen a posteriori to define $\mathrm{QBO}$ phase, in order to maximize the correlation with extratropical variables (Baldwin and Dunkerton, 1989; Anstey and Shepherd, 2014); on the other hand, the correlation between QBO phases and wave intensities obtained in these studies should be opposite, because zonal winds of the QBO vary or even reverse with altitude. Miyoshi and Hirooka (2003) define QBO phase by the vertical shear of zonal-mean zonal wind between $70 \mathrm{hPa}$ and $10 \mathrm{hPa}$ at the equator, and find clear QBO variations in the amplitudes of 5-day-waves (5DWs). This result implies that the entire altitude range of the QBO zonal winds jointly influence global atmospheric dynamics. Accordingly, it would seem wise to focus on figuring out relations between the 6.5DWs and the full vertical profile of the corresponding QBO if we wish to understand better how QBOs may be modulating the 6.5DWs.

A reasonable way to define QBO phases is by empirical orthogonal functions (EOFs, Li Y et al., 2019), considering the entire vertical profiles of the QBO in the lower stratosphere (Wallace et al., 1993; Fraedrich et al., 1993; Anstey et al., 2010; Solomon et al., 2014). The first two principal components of the stratospheric zonal mean winds can define distinct oscillations with period of approximately 28-months (Fraedrich et al., 1993). By utilizing EOFs, Solomon et al. (2014) have reproduced both vertical structures and temporal oscillating features of the QBO that fit the physical description based on a general circulation model (GCM). QBO phases can be calculated quantitatively by adopting these two principal components as introduced by Fraedrich et al. (1993) and Wallace et al. (1993).

PW characteristics have been extensively studied, based on satellite observations such as: High Resolution Doppler Imager/Upper Atmosphere Research Satellite (HRDI/UARS) (Wu DL et al., 1994; Talaat et al., 2002), advanced Sub-Millimetre Radiometer (SMR)/ Odin (Belova et al., 2008), Microwave Limb Sounder (MLS)/Aura (Pancheva et al., 2018; Qin YS et al., 2021), Sounding of the Atmosphere by Broadband Emission Radiometry/Thermosphere Ionosphere Mesosphere Energetics and Dynamics (SABER/TIMED) (Li T et al., 2008; Huang YY et al., 2013, 2017; Gan Q et al., 2015; Gu SY et al., 2019), and TIMED Doppler interferometer (TIDI) (Gan Q et al., 2015; Gu SY et al., 2018). Among these observations, SABER/ TIMED supplies the best spatiotemporal coverage and data preci- 
sion; accordingly, it is widely used in studies of basic atmospheric structures (Xu JY et al., 2007) and atmospheric waves: gravity waves (GWs) (John and Kumar, 2012; Shuai et al., 2014; Liu X et al., 2020), tides (Zhang et al., 2006; Li X et al., 2015; Liu MH et al., 2016; Li X et al., 2020), and PWs (García-Comas et al., 2008; Li T et al., 2008; Huang YY et al., 2013).

Since this work studies inter-annual variations of 6.5DWs and their relations with the QBO, we have used SABER/TIMED measurements from 30 to $110 \mathrm{~km}$ between $52^{\circ} \mathrm{S}-52^{\circ} \mathrm{N}$ during January 2002-March 2021 to derive inter-annual variations of 6.5DWs in kinetic temperature $\left(T_{k}\right)$. QBO wind data from 70 to $5 \mathrm{hPa}$ between $5^{\circ} \mathrm{S}-5^{\circ} \mathrm{N}$ from January 2002-December 2020 are obtained from the European Centre for Medium-Range Weather Forecasts (ECMWF) Re-Analysis of the $5^{\text {th }}$ (ERA5) dataset (Hersbach et al., 2020). QBO phases are calculated by an EOF method as proposed by Fraedrich et al. (1993) and Wallace et al. (1993). Data and processes utilized in this paper are introduced in Section 2; inter-annual variation characteristics of 6.5DWs are shown in Section 3; relations between inter-annual variations of 6.5DWs and the QBO are shown in Section 4; discussion and conclusions are presented in Sections 5 and 6, respectively.

\section{Data and Processes}

\subsection{V2.0 $T_{k}$ from SABER/TIMED Observations}

The TIMED satellite was launched from Vandenberg Air Force Base on 7 December 2001. As a polar-orbiting satellite, TIMED makes about 15 orbits per day in a $625 \mathrm{~km}$ and $74^{\circ}$ inclination orbit. SABER is an instrument onboard TIMED. It has been performing global measurements of atmospheric temperature, density, and mixing ratios of certain chemical species, such as $\mathrm{O}_{3}, \mathrm{H}_{2} \mathrm{O}, \mathrm{CO}_{2}$, etc., since 25 January 2002. Through measuring the atmosphere using a 10-channel broadband limb-scanning infrared radiometer covering the spectral range from $1.27 \mu \mathrm{m}$ to $17 \mu \mathrm{m}$, SABER can provide vertical profiles of kinetic temperature $T_{k}$ from the lower stratosphere to the lower thermosphere $(\sim 15-110 \mathrm{~km})$. In this paper, v2.0 level 2A SABER $T_{k}$ data within $54^{\circ} \mathrm{S} / \mathrm{N}$ and from 30 to 110 $\mathrm{km}$ are adopted. This version of SABER results is reliable and selfconsistent (Rezac et al., 2015). Datasets obtained by SABER/TIMED can be downloaded from ftp://saber.gats-inc.com/.

Before processing, $T_{k}$ series are binned into 27 latitude bands with $4^{\circ}$ intervals. Each vertical profile of $T_{k}$ is linearly interpolated into $1 \mathrm{~km}$ resolution. In a given latitude band, SABER takes 60 days to cover 24 hours in local time. As a result, background temperature $T$ at each altitude level and latitude band is calculated by averaging $T_{k}$ in a 60-day window by 1-day running steps.

\subsection{ERA5 Dataset}

ERA5 is ECMWF's latest comprehensive atmospheric reanalysis (Simmons et al., 2020), which is based on the Integrated Forecast- ing System (IFS) Cy41r2; it provides an enhanced number of output parameters covering periods from 1950 to present (Hersbach et al., 2020). The ERA5 dataset can be found at https://apps.ecmwf.int/data-catalogues/era5/?class=ea. For QBO data needed in this paper, we have chosen monthly means of daily mean zonalmean zonal wind between $5^{\circ} \mathrm{S}$ and $5^{\circ} \mathrm{N}$ with a spatial resolution of $0.25^{\circ} \times 0.25^{\circ}$ (latitude $\times$ longitude) at $70,50,30,20,10,7$ and $5 \mathrm{hPa}$ from January 2002 to December 2020.

\subsection{QBO Phases Obtained by the EOF Method}

“Deseasonalized" $\mathrm{QBO}\left(\mathrm{QBO}_{D}\right)$ data are calculated first by subtracting 2002-2020 averaged QBO. As a result, inter-annual variations of the $\mathrm{QBO}$ are eliminated. The EOF is then applied to the $\mathrm{QBO}_{D}$ fields and seven principal components are decomposed. Table 1 shows percentages of each EOF variance and the corresponding running total value; the first two variances contribute $91.17 \%$ of the total variance, which is slightly less than the $93.42 \%$ reported by Fraedrich et al. (1993). This discrepancy may result from the shorter periods considered here. However, our result is sufficiently similar to the findings of Fraedrich et al. (1993) and Wallace et al. (1993) to confirm that the sum of the first two EOF components can be used to reconstruct reasonable QBO fields. Absolute differences between the reconstructed $\mathrm{QBO}_{D}$ and original $\mathrm{QBO}_{D}$ are generally within $6 \mathrm{~m} / \mathrm{s}$ (results are not shown here) except during 2015-2016, when the QBO was in its anomalous period (Newman et al., 2016; Lin P et al., 2019; Bai XY wt al., 2021). Figure 1a shows temporal variations of the first and second EOF componenets $\left(\mathrm{EOF}_{1}\right.$, solid line; $\mathrm{EOF}_{2}$, dashed line). Figure $1 \mathrm{~b}$ shows vertical variations of $\mathrm{EOF}_{1}$ and $\mathrm{EOF}_{2}$.

Figure $1 \mathrm{~b}$ shows two vertical maximums in both $\mathrm{EOF}_{1}$ and $\mathrm{EOF}_{2}$, respectively. The negative maximum of $\mathrm{EOF}_{1}$ emerges at $7 \mathrm{hPa}$ and the positive maximum emerges at $30 \mathrm{hPa}$, while for $\mathrm{EOF}_{2}$ they are at 50 and $20 \mathrm{hPa}$, respectively. It is notable that absolute values of these maximums are more remarkable at altitudes above $30 \mathrm{hPa}$. Vertical peaks of each EOF component indicate vertical regions where the EOF component can best be demonstrated. For example, EOF 1 exhibits QBO dynamics mainly around 30 and $7 \mathrm{hPa}$. Figure 1a shows that temporal variations of EOF 1 and EOF have a nearly stable 1-quarter phase difference, caused by downward propagation and temporal variations of the $\mathrm{QBO}$ zonal wind.

Figure 2a shows time series of EOF 2 varying with EOF 1 . Both EOF and $\mathrm{EOF}_{2}$ are normalized by $2 / \max \left(\left[\mathrm{EOF}_{1}, \mathrm{EOF}_{2}\right]\right)$. The center of the variation circle is marked by a red plus sign. Its coordinate is $[-0.17,-0.02]$. Following definitions by Wallace et al. (1993), amplitudes $(C)$ and phases $\left(P_{\mathrm{QBO}}\right)$ of the $\mathrm{QBO}$ are calculated as follows:

$$
\left\{\begin{array}{l}
C=\left(A_{1}^{2}+A_{2}^{2}\right)^{1 / 2}, \\
P_{\mathrm{QBO}}=\frac{1}{2 \pi} \tan ^{-1}\left(\frac{A_{2}}{A_{1}}\right),
\end{array}\right.
$$

Table 1. The contribution of the seven EOFs to the total variance (\%).

\begin{tabular}{ccccccccc}
\hline Number of EOF & 1 & 2 & 3 & 4 & 5 & 6 & 7 \\
\hline Percent of variance (\%) & 49.79 & 41.38 & 4.10 & 2.65 & 1.21 & 0.55 & 0.32 \\
Running total (\%) & 49.79 & 91.17 & 95.27 & 97.92 & 99.13 & 99.68 & 100.00 \\
\hline
\end{tabular}



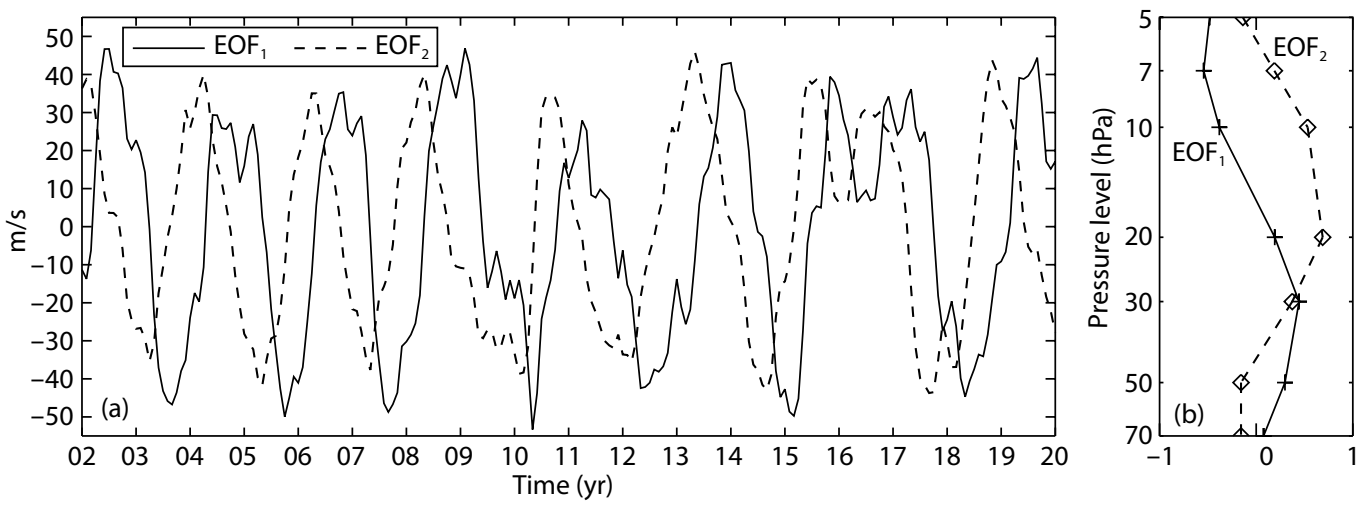

Figure 1. (a) Temporal variations of EOF 1 (solid line) and EOF 2 (dashed line). (b) Vertical structures of EOF 1 (solid line with plus signs) and EOF 2 (dashed line with diamonds).
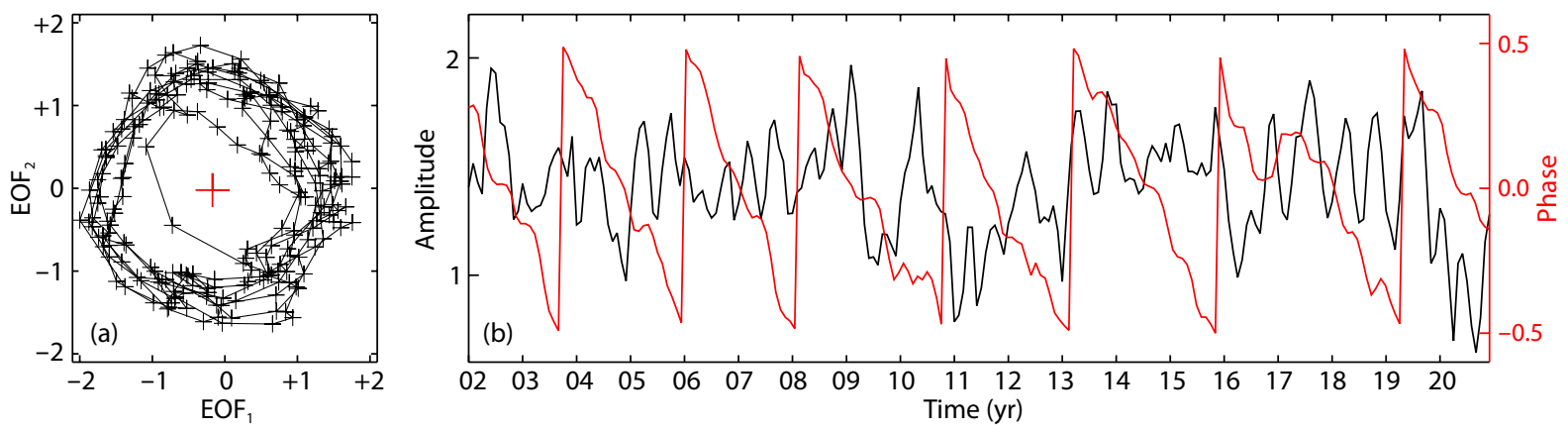

Figure 2. (a) Time series of EOF 1 varying with $\mathrm{EOF}_{2}$. Values of both $\mathrm{EOF}_{1}$ and $\mathrm{EOF}_{2}$ are normalized by $2 / \mathrm{max}_{(}\left(\left[\mathrm{EOF}_{1}, \mathrm{EOF}_{2}\right]\right)$. The red plus sign indicates the center of the circle at $[-0.17,-0.02]$. (b) Temporal variations of QBO amplitudes (black, corresponding to the left $y$-axis) and phases (red, corresponding to the right $y$-axis).

in which, $A_{1}$ and $A_{2}$ indicates time series of $\mathrm{EOF}_{1}$ and $\mathrm{EOF}_{2}$ shown in Figure 1a, respectively. Figure $2 \mathrm{~b}$ demonstrates $\mathrm{QBO}$ amplitudes (black line) and phases (red line). Please notice that the QBO phase is normalized to $(-0.5,0.5)$ by $P_{\mathrm{QBO}} / 2 \pi$.

The circle in Figure 2a shows vertical variations of the QBO. The circles are drawn continuously in a clockwise direction. Each single circle represents a full QBO period. To explain this figure more clearly, the circles are divided into the upper and the lower parts, the upper parts denoting progression in which EOF in- $_{1}$ creases from the negative maximum to the positive maximum, and $\mathrm{EOF}_{2}$ increases from 0 to the maximum and returns back to 0 . Recalling the vertical structures of $\mathrm{EOF}_{1}$ and $\mathrm{EOF}_{2}$ shown in Figure $1 b$, it is clear that the upper part of the circle represents the change of $\mathrm{QBO}$ winds around $7 \mathrm{hPa}$ from maximum westerly to maximum easterly while the $\mathrm{QBO}$ westerly wind around $20 \mathrm{hPa}$ grows from 0 to its maximum and then decreases again to $0 . \mathrm{QBO}$ dynamical processes at the lower part of the circle can be deduced correspondingly. The arc tracks at the right part of the circle, where EOF 1 is positive, vary more at different $\mathrm{QBO}$ periods than do the tracks at the left part of the circle. Considering relative strengths of EOF 1 and $\mathrm{EOF}_{2}$, these results suggest that the QBO structure is more unstable when the $\mathrm{QBO}$ wind is easterly at $7 \mathrm{hPa}$.

QBO amplitudes (black line) during 2002-2020 shown in Figure 2b have weak annual variations. From temporal variations of phases (red line), periods of the QBO can be calculated. In general, the
QBO cycle varies from 24 to 31 months; the average is 27.8 months. During the abnormal period from 2016 to 2019, the QBO period extended to 39 months.

\section{Long-term Variations of 6.5DWs}

Daily amplitudes of 6.5DWs ( $A$ ) from March 2002 to January 2021 are calculated through the least squares fitting method of harmonic functions: $f(A, \varphi)=A \cdot \cos (\omega t-s \lambda-\varphi)$, in which $A, \varphi, \omega$ and $s$ are amplitude, phase, angular frequency, and zonal wavenumber of the wave component, and $t$ and $\lambda$ are universal time and longitude of the observation point. This data processing method is similar to that adopted by Huang YY et al. (2017). We find that the temperature field of the 6.5DWs exhibits prominent amplitudes at $30^{\circ}-50^{\circ} \mathrm{S} / \mathrm{N}$. The enhanced wave activity usually lasts for about two wave periods, which is similar to the findings of previous studies (Jiang G et al., 2008a; Merzlyakov et al., 2013; Pancheva et al., 2018); this result confirms that it is reasonable to study long term variations of 6.5DWs based on 15-day-averaged wave amplitudes ( $\left.\bar{A}_{15 d}\right)$ (Pancheva et al., 2018).

At each latitude band and altitude level, calculation of $\bar{A}_{15 d}$ is as:

$$
\bar{A}_{15 d}(d, h, l)=\frac{1}{15} \sum_{i=1}^{15} A_{d_{i}, h, l}
$$

in which $d, h, l$ indicate index of time window, altitude, and latitude, respectively; $i$ is index of day in a time window; overbar ' $\bar{A}$ ' 
means averaged value. The results show that temporal and vertical variations of $\bar{A}_{15 d}$ are similar from $30^{\circ}$ to $50^{\circ}$ latitude in both hemispheres (not shown here), which is in accordance with previous results (Talaat et al., 2001; Riggin et al., 2006). To study variations of 6.5DWs in mid-high latitudes of both hemispheres, $\bar{A}_{15 d}$ is averaged over the $30^{\circ}-50^{\circ}$ latitude band. Figure 3 shows temporal variations of $\bar{A}_{15 d}$ during March 2002-January 2021 from 20 to $110 \mathrm{~km}$ in (a) $30^{\circ} \mathrm{N}-50^{\circ} \mathrm{N}$ and (b) $30^{\circ} \mathrm{S}-50^{\circ} \mathrm{S}$. We observe that $\bar{A}_{15 d}$ has three separated vertical peaks in both hemispheres: at 40$50 \mathrm{~km}, 80-90 \mathrm{~km}$, and $100-110 \mathrm{~km}$, respectively. At $40-50 \mathrm{~km}$, $\bar{A}_{15 d}$ varies annually, while at $80-90$ and $110 \mathrm{~km}$, it varies semi-annually. In addition, at all of those levels $\bar{A}_{15 d}$ varies inter-annually as well. $\bar{A}_{15 d}$ in the $\mathrm{SH}$ is weaker than in the $\mathrm{NH}$; its inter-annual variation features differ between the hemispheres.

Between February 2002 and January 2021, the predominant periods of long-term variation in the 6.5DWs at 80-90 and 100$110 \mathrm{~km}$, between $30^{\circ}-50^{\circ} \mathrm{N} / \mathrm{S}$, were 12 -month and 6-month. Also observed were relatively weak spectral peaks at a period of around 28-months (Huang YY et al., 2017). Possible relations between long-term variations of $6.5 \mathrm{DWs}$ and equatorial stratospheric QBO have been suggested (Miyoshi and Hirooka, 2003; Kishore et al., 2004; Lima et al., 2005; Pancheva et al., 2010; 2018;
Merzlyakov et al., 2013). However, quantitative observational evidence of this relationship has been lacking.

Considering strong annual variations of 6.5DWs, composite amplitudes averaged from February 2002 to January 2021 are obtained, and then they are removed from temporal series of 6.5DWs' amplitudes before further study. As was mentioned before, temporal variations of $6.5 \mathrm{DWs}$ are similar between $30^{\circ}-50^{\circ}$ in each hemisphere. So composite amplitudes are averaged over $30^{\circ} \mathrm{N}-50^{\circ} \mathrm{N}$ and $30^{\circ} \mathrm{S}-50^{\circ} \mathrm{S}$, respectively. The variations with time and altitude of the averaged amplitudes are shown in Figure 4.

Composite amplitudes observed at $30^{\circ} \mathrm{N}-50^{\circ} \mathrm{N}$ exhibit obvious maximums from 80 to $110 \mathrm{~km}$ during April-May and AugustSeptember; maximums at $30^{\circ} \mathrm{S}-50^{\circ} \mathrm{S}$ emerge during February and November at altitudes similar to those in the North. Amplitudes in the $\mathrm{NH}$ are 1-2 $\mathrm{K}$ larger than in the $\mathrm{SH}$. Large composite 6.5DW amplitudes in both hemispheres last for about one to two months. Temporal variations of composite amplitudes in the $\mathrm{NH}$ are more intense than in the $\mathrm{SH}$, which indicates weaker inter-annual variations of $6.5 \mathrm{DWs}$ in the $\mathrm{NH}$ than in the $\mathrm{SH}$. In the stratosphere, annual maximums in both hemispheres can also been noticed during winters, i.e. January and December in the $\mathrm{NH}$ and

(a) $30^{\circ} \mathrm{N}-50^{\circ} \mathrm{N}$

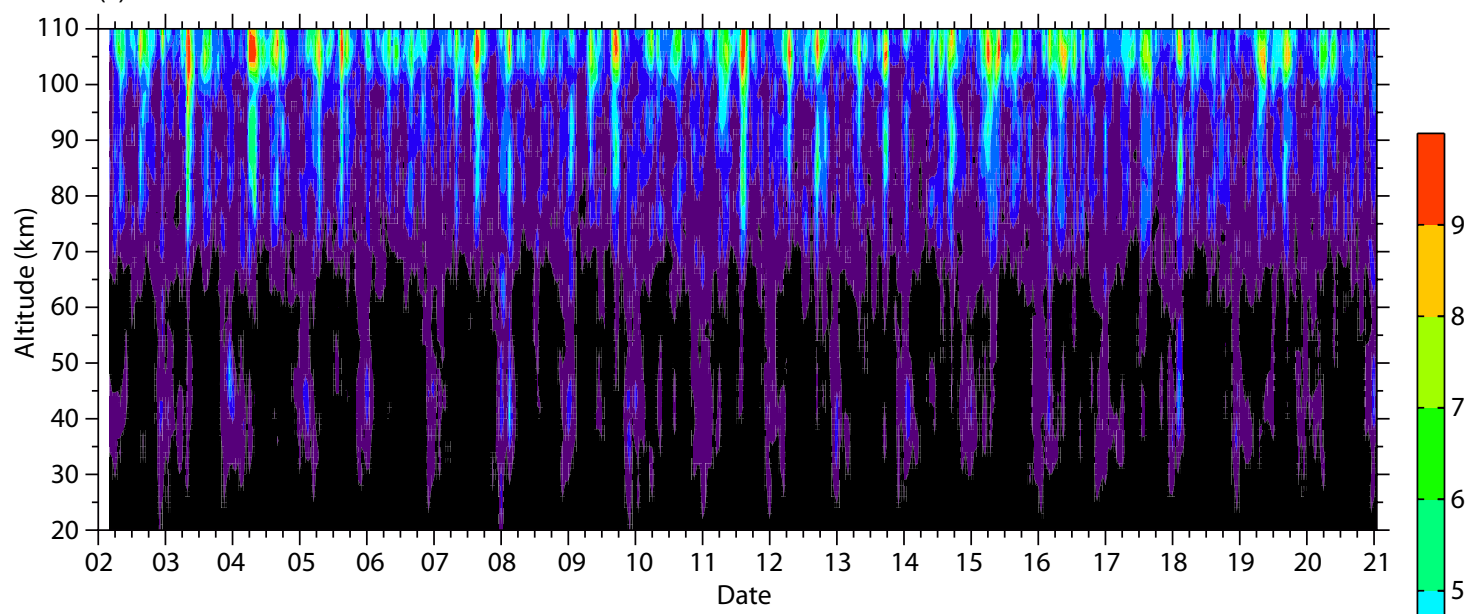

(b) $30^{\circ} \mathrm{S}-50^{\circ} \mathrm{S}$

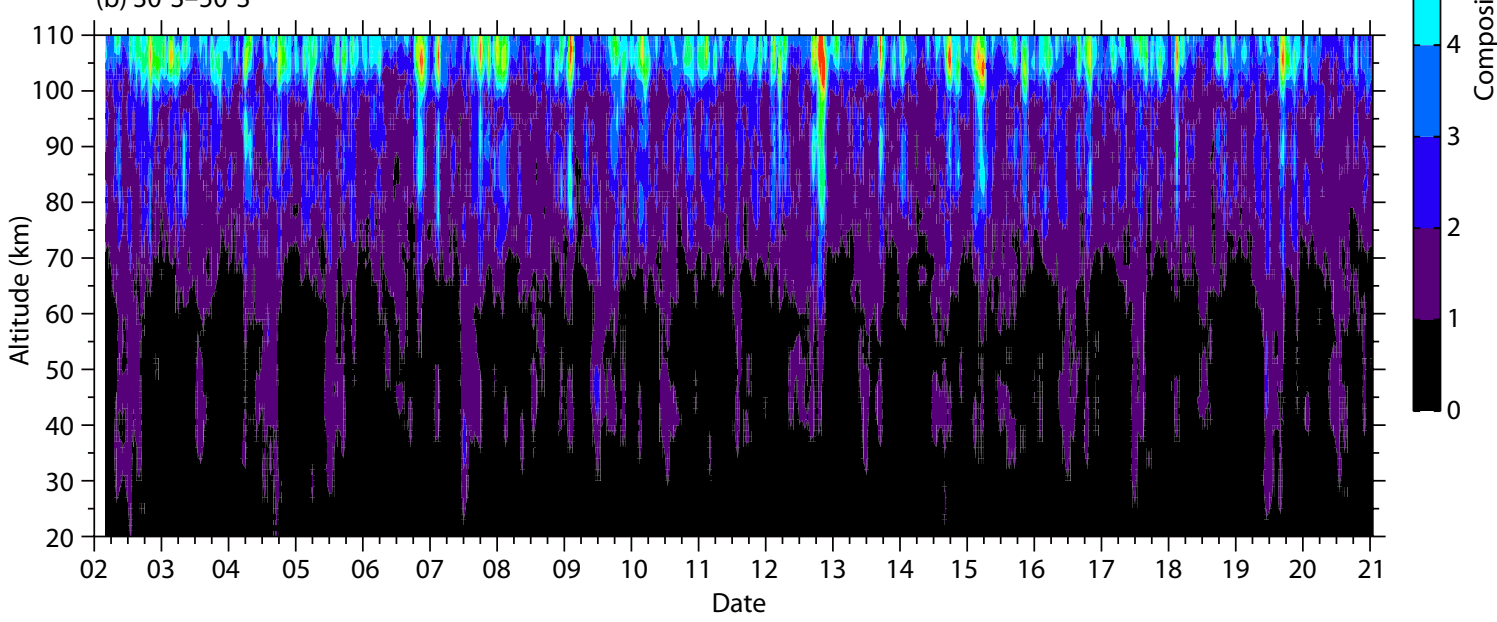

Figure 3. Temporal variations of 15 -day averaged $6.5 \mathrm{DW}$ amplitudes $\left(\bar{A}_{15 d}\right)$ from 20 to $110 \mathrm{~km}$. Panels (a)/(b) demonstrate results for $30^{\circ}-50^{\circ}$ in the Northern/Southern hemispheres, respectively. 
(a) $30^{\circ} \mathrm{N}-50^{\circ} \mathrm{N}$

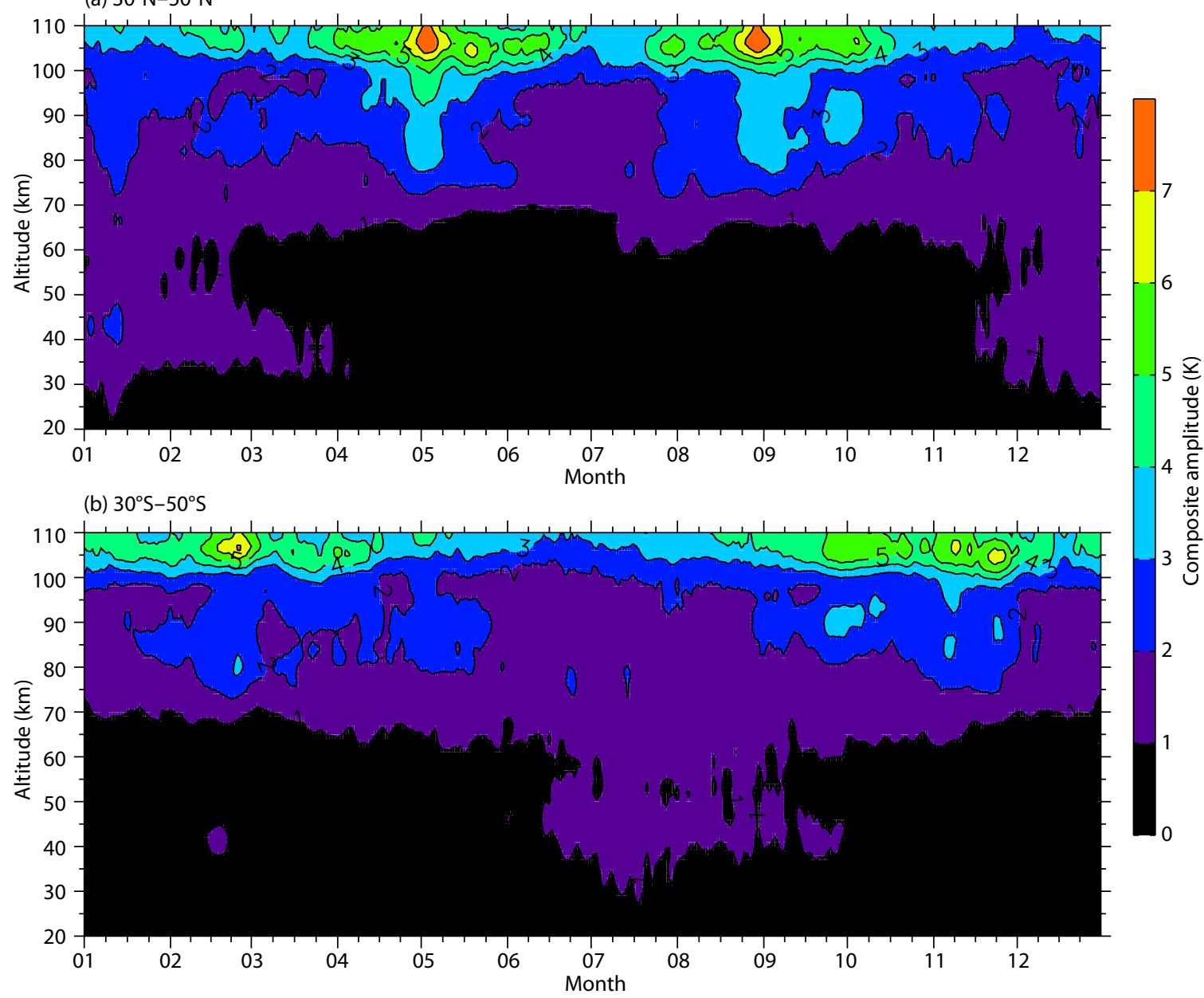

Figure 4. Day-to-Day variations of 6.5DW composite amplitudes averaged from February 2002 to January 2021. Panel (a)/(b) shows results obtained between $30^{\circ}-50^{\circ}$ in the Northern/Southern hemispheres.

July-August in the $\mathrm{SH}$, but their amplitudes are generally less than $3 \mathrm{~K}$, much smaller than in the MLT region. Thus, here we consider inter-annual variations of 6.5DWs only in the MLT.

Inter-annual variations of 6.5DWs' amplitudes are superpositions of oscillations with different periods and stochastic noises. Residual amplitudes of 6.5DWs are obtained by removing composite amplitudes (Figure 4) from original amplitudes day-by-day at each altitude level and latitude band. This method suppresses seasonal variations of the 6.5DWs, allowing their longer periods to be more effectively recognized and extracted. Figure 5 shows time-altitude sections of 15-day averaged residual amplitudes of 6.5DWs from 70 to $110 \mathrm{~km}$ at (a) $30^{\circ} \mathrm{N}-50^{\circ} \mathrm{N}$ and (b) $30^{\circ} \mathrm{S}-50^{\circ} \mathrm{S}$. We can see obvious inter-annual variations in both panels. To find exact periods in long-term variations of the residual amplitudes, wavelet spectral analytical method is employed.

Wavelet transform parameters are set as 6th-order 'Morlet' wavelet base functions. Figure 6 shows time-spectral period sections of wavelet spectral power of 15-day-averaged residual 6.5DWs amplitudes at $85 \mathrm{~km}$. Panels $(\mathrm{a}-\mathrm{e}) /(\mathrm{f}-\mathrm{j})$ show results at $32^{\circ} \mathrm{N}-48^{\circ} \mathrm{N} /$ $32^{\circ} \mathrm{S}-48^{\circ} \mathrm{S}$, respectively. In the $\mathrm{NH}$ during $2010-2016$, a spectral peak around $28-$ month is obvious at $32^{\circ} \mathrm{N}$ and $36^{\circ} \mathrm{N}$. The period of this spectral peak increases with poleward latitude; at $52^{\circ} \mathrm{N}$, the period reaches almost 40 months. Power spectra at $40^{\circ} \mathrm{N}$ show temporal variations that differ from results at other latitude bands in the $\mathrm{NH}$. The spectral peak around 36 months is much weaker during 2010-2016; a comparable spectral peak of roughy 24 months appears during 2005-2009. In the $\mathrm{SH}$, the dominant spectral peak period during $2008-2016$ between from $32^{\circ} \mathrm{S}$ and $48^{\circ} \mathrm{S}$ is approximately 28 months; this $\mathrm{SH}$ peak's spectral period is more stable with latitude than is observed in the $\mathrm{NH}$. At $48^{\circ} \mathrm{S}$, spectral powers at all periods from 18 to 60 months are generally weak, less than $3 \mathrm{~K}$.

Wavelet spectral power of the 15-day averaged residual 6.5DW's amplitudes changes with latitude, and exhibits inter-hemispheric asymmetry. Periods of these spectral peaks range from roughly 24-36 months, which closely match the QBO period. It is thus reasonable to speculate that these peaks are probably modulated by the equatorial QBO through wave-flow and/or wave-wave interactions, as the poleward and upward propagations of the QBO and planetary waves are related with the generation of $6.5 \mathrm{DWs}$. If so, these results indicate a possible doppler shift of "QBO-like" signals in 6.5DWs, the wave-flow and/or wave-wave interaction processes differing from stratosphere to MLT regions in both hemispheres. Study of these processes is beyond the scope of this pa- 
(a) $30^{\circ} \mathrm{N}-50^{\circ} \mathrm{N}$

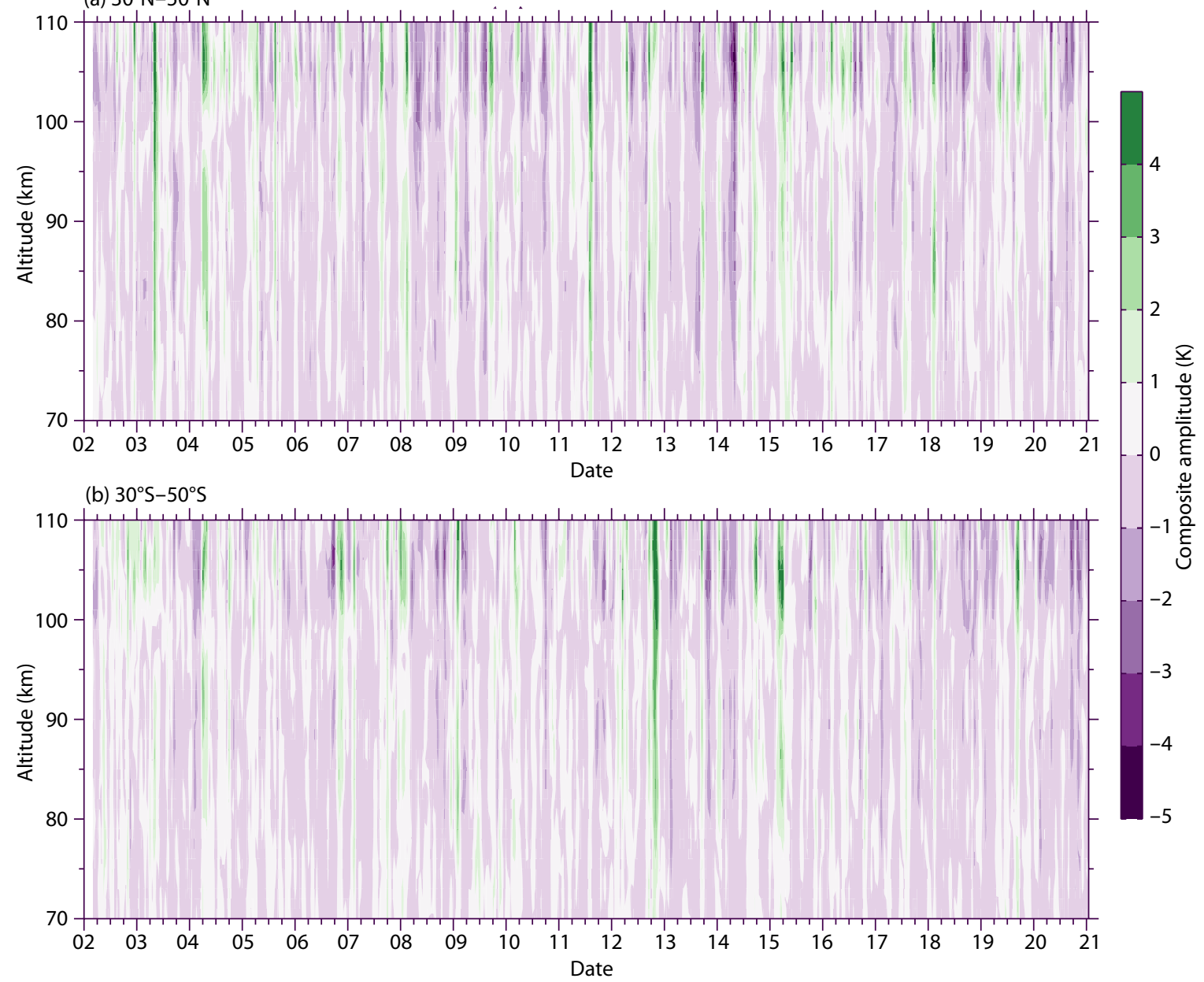

Figure 5. Time-altitude sections of 15 -day averaged residual $6.5 \mathrm{DWs}$ amplitudes, averaged (a) from $30^{\circ} \mathrm{N}$ to $50^{\circ} \mathrm{N}$ and (b) from $30^{\circ} \mathrm{S}$ to $50^{\circ} \mathrm{S}$.
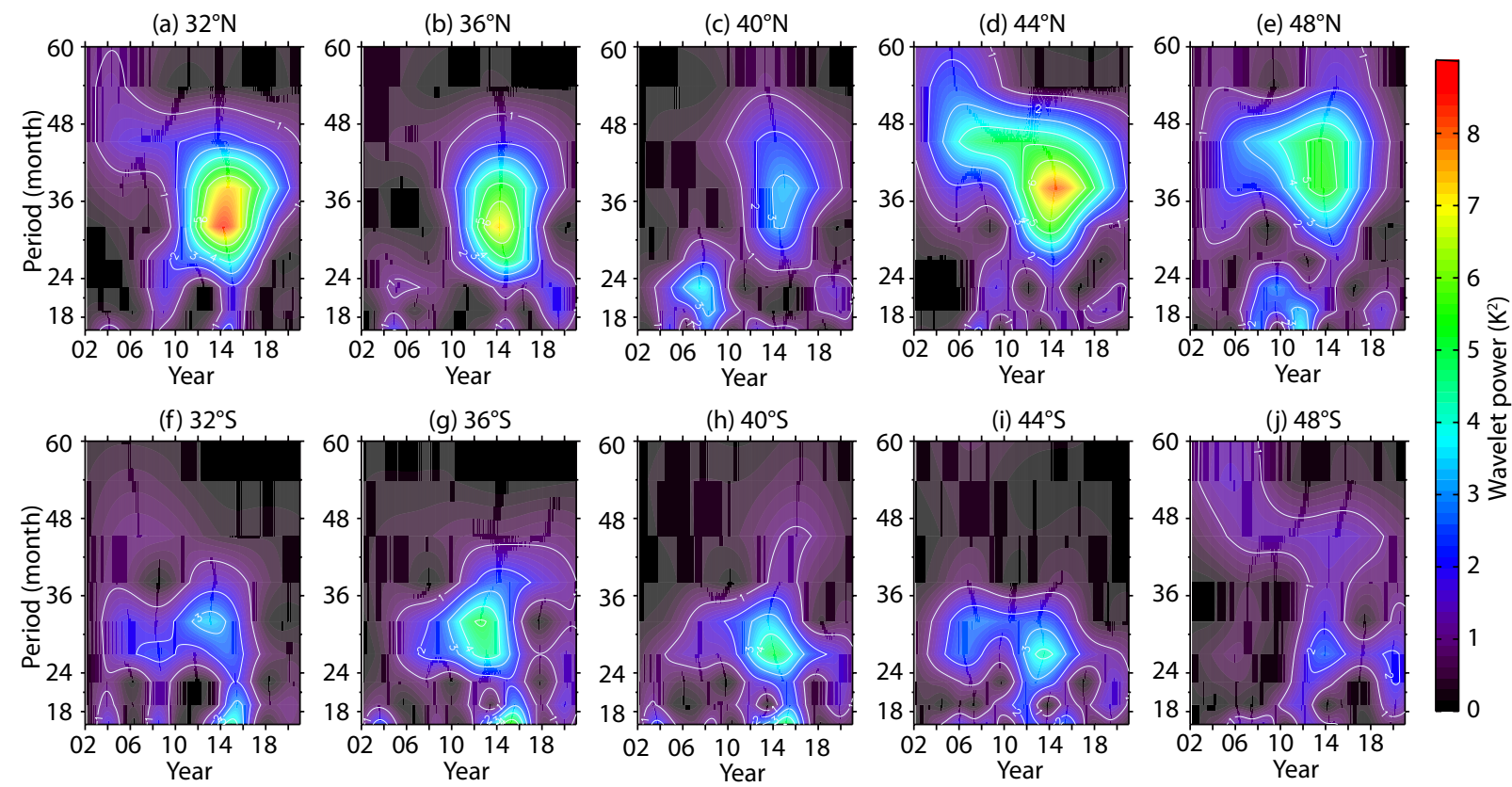

Figure 6. Wavelet spectral power of 15 -day averaged residual $6.5 \mathrm{DWs}^{\prime}$ amplitudes at $85 \mathrm{~km}$ in $30^{\circ}-50^{\circ} \mathrm{N} / \mathrm{S}$, changing with time and period. Title of each panel shows latitude band. 
(a) $32^{\circ} \mathrm{N}$

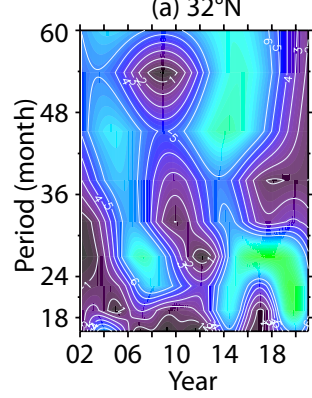

(f) $32^{\circ} \mathrm{S}$

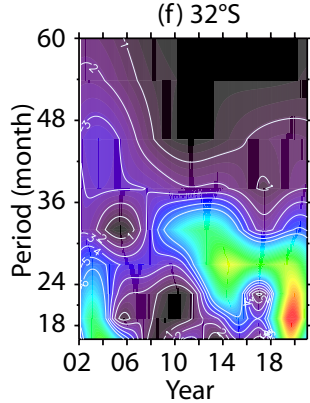

(b) $36^{\circ} \mathrm{N}$

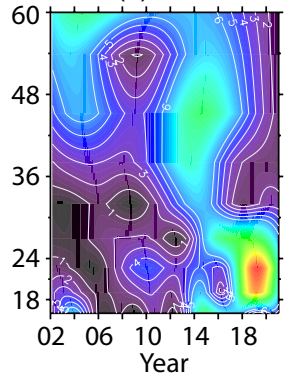

(g) $36^{\circ} \mathrm{S}$

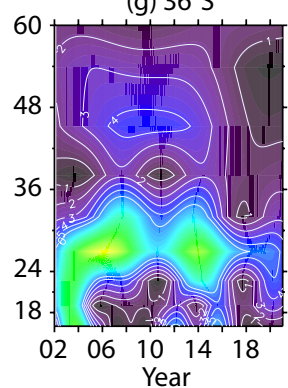

(c) $40^{\circ} \mathrm{N}$

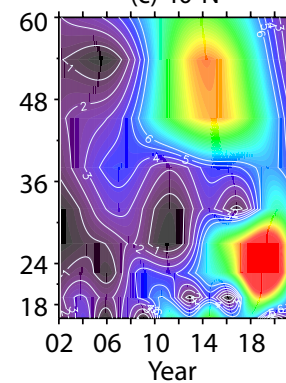

(h) $40^{\circ} \mathrm{S}$

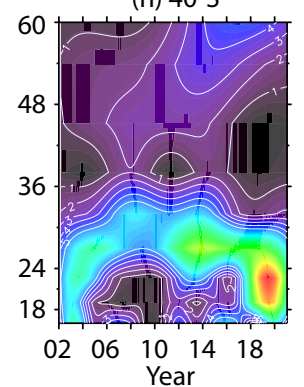

(d) $44^{\circ} \mathrm{N}$

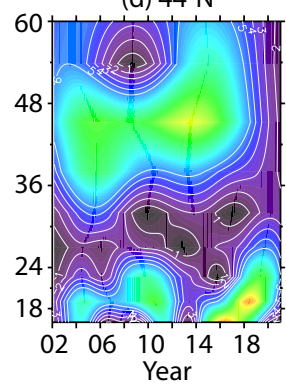

(i) $44^{\circ} \mathrm{S}$

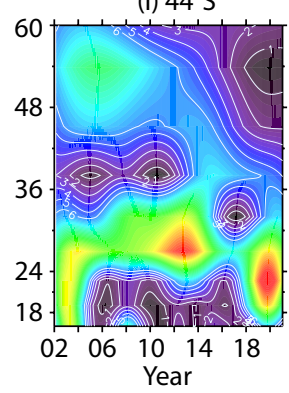

(e) $48^{\circ} \mathrm{N}$

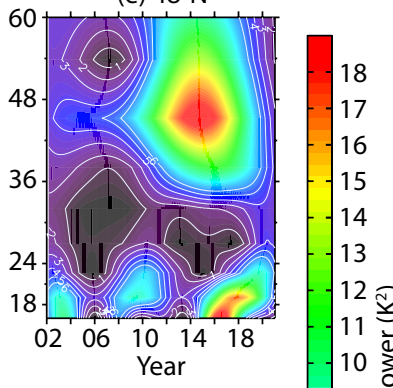

(j) $48^{\circ} \mathrm{S}$

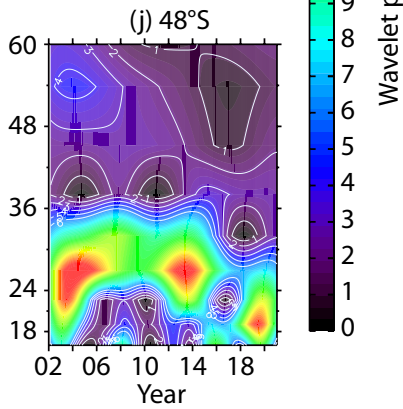

Figure 7. Similar as Figure 6, but for wavelet spectra of residual amplitudes at $105 \mathrm{~km}$.

per. We plan to perform further model studies in the future to explain these phenomena.

Figure 7 shows wavelet spectral amplitudes as in Figure 6, but for results at $105 \mathrm{~km}$. In the $\mathrm{NH}$, strong spectral power exists at two separate periods, around 48 and 24 months, respectively. Spectral power around 48 months is the strongest at $48^{\circ} \mathrm{N}$, while spectral power around 24 months increases with latitude, poleward from $32^{\circ} \mathrm{N}$ to $40^{\circ} \mathrm{N}$. At $44^{\circ} \mathrm{N}$ and $48^{\circ} \mathrm{N}$, this spectral peak is statistically insignificant. In the $\mathrm{SH}$, a period of peak spectral power exists stably around 28 months during almost the entire period 2002-2020.

It can be noticed from Figures 6 and 7 that, at latitudes $32^{\circ}-48^{\circ}$ in the $\mathrm{SH}$, spectral peaks around 28 months are persistently remarkable from 2002 to 2020 at both altitude levels; this observation is an indirect indication of QBO signals in the inter-annual variations of 6.5DWs amplitudes in MLT regions at these mid-high latitudes of the $\mathrm{SH}$, implying possible QBO modulation of 6.5DWs. At both altitude levels in the $\mathrm{NH}$, wavelet spectral peaks emerge at relatively longer periods, i.e. 30-38 months at $85 \mathrm{~km}$, and 40-48 months at $105 \mathrm{~km}$; an additional, separate, spectral peak at 24 months is noticeable: at $40^{\circ} \mathrm{N}$ and $48^{\circ} \mathrm{N}$, an $85 \mathrm{~km}$ peak; at $32^{\circ} \mathrm{N}$ to $40^{\circ} \mathrm{N}$, a $105 \mathrm{~km}$ peak.

The wavelet analytical method identifies spectral power at discrete periods. The closest periods to the QBO are 26.9 and 32.0 months. Spectral power at these two periods are averaged to obtain 'QBO-like' signals in inter-annual variations of 6.5DWs. Timelatitude sections of the averaged spectral power at 75, 85, 95 and $105 \mathrm{~km}$ are shown in panels $(\mathrm{a}-\mathrm{d})$ of Figure 8. Please notice that contour levels are different at these four altitudes. Vertical changes of the averaged power in the $\mathrm{NH}$ are different from those in the $\mathrm{SH}$. In the $\mathrm{NH}$, 'QBO-like' power is more remarkable at 85 and $105 \mathrm{~km}$. This vertical variation is similar to that of $6.5 \mathrm{DWs}^{\prime}$ amplitudes. It has been shown that 6.5DWs propagate upward from 70 to $110 \mathrm{~km}$ (Kishore et al., 2004; Jiang G et al., 2008a; Merzlyakov et al., 2013). The non-monotonic features of 'QBO-like' power from 75 to $105 \mathrm{~km}$ shown in Figure 8 imply different origins of QBO signals in 6.5DWs at 85 and $105 \mathrm{~km}$.

\section{Relations Between 6.5DWs and QBO}

\subsection{Comparisons Between 6.5DWs' $A_{M \max }$ and QBO Wind}

Wavelet spectral analytical results obtained in Section 3 confirm that QBO-related signals can be detected in long-term variations of 6.5DWs' amplitudes. In this section, 6.5DW strength is compared with vertical profiles of the QBO. The monthly strength of 6.5DWs is represented by their monthly maximum residual amplitudes $\left(A_{\text {Mmax }}\right)$. Residual 6.5DW amplitudes $\left(A_{r}\right)$ are obtained by subtracting composite amplitudes from original amplitudes.

Figure 9a shows the time-altitude section of $30^{\circ} \mathrm{N}-50^{\circ} \mathrm{N}$ averaged $A_{\text {Mmax }}$. The annual maximum values of $A_{\text {Mmax }}$ from $30^{\circ}-50^{\circ} \mathrm{S} / \mathrm{N}$ at 70-110 km and their occurring months are presented for each year from 2002 to 2020. These nineteen annual maximums are sorted, and QBO profiles at these months are analysed statistically. Figures $9 \mathrm{~b}$ and $9 \mathrm{c}$ show QBO profiles at the months of the eight weakest and eight strongest annual maximums, respectively. The thick black curve with error bars is the mean zonal wind profile. The annual maximum amplitudes of 6.5DWs and their corresponding months are shown at the right side of each panel. Colors of the curves are in accordance with the caption.

Table 2 lists the annual maximums $A_{\text {Mmax }}$ observed between $30^{\circ} \mathrm{N}$ and $50^{\circ} \mathrm{N}$ from 70 to $110 \mathrm{~km}$ during 2002-2020, their occurring months, and their ranks. From the calculation of the $A_{M m a x}$ it seems apparent, on the one hand, that substantial variations (with periods of one-year and six-months) have been erased, and, on the other hand, that QBO-like signals clearly remain in the adjus- 
(a) $75 \mathrm{~km}$

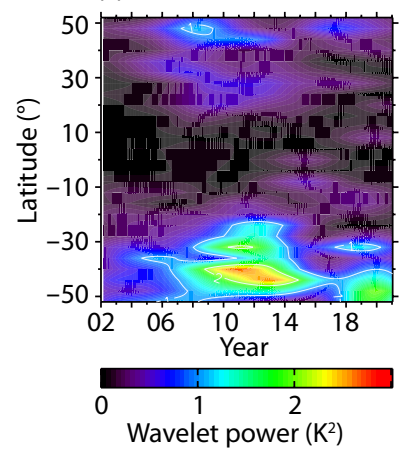

(b) $85 \mathrm{~km}$

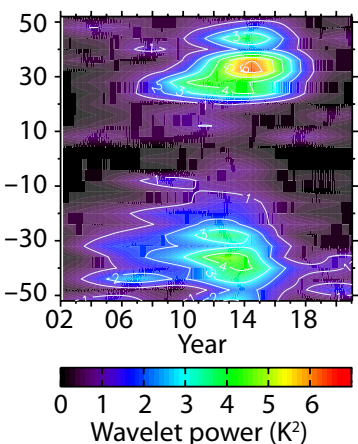

(c) $95 \mathrm{~km}$

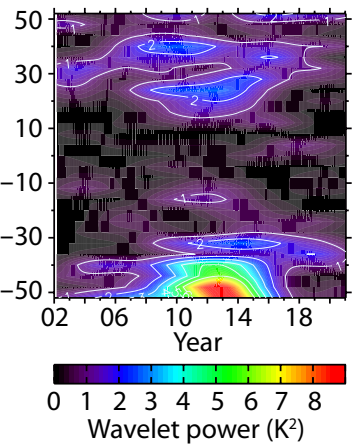

(d) $105 \mathrm{~km}$

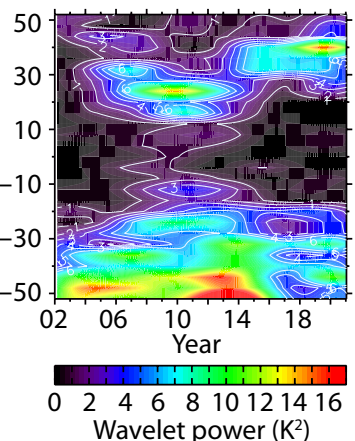

Figure 8. Time-latitude variations of wavelet spectral power at QBO's period.
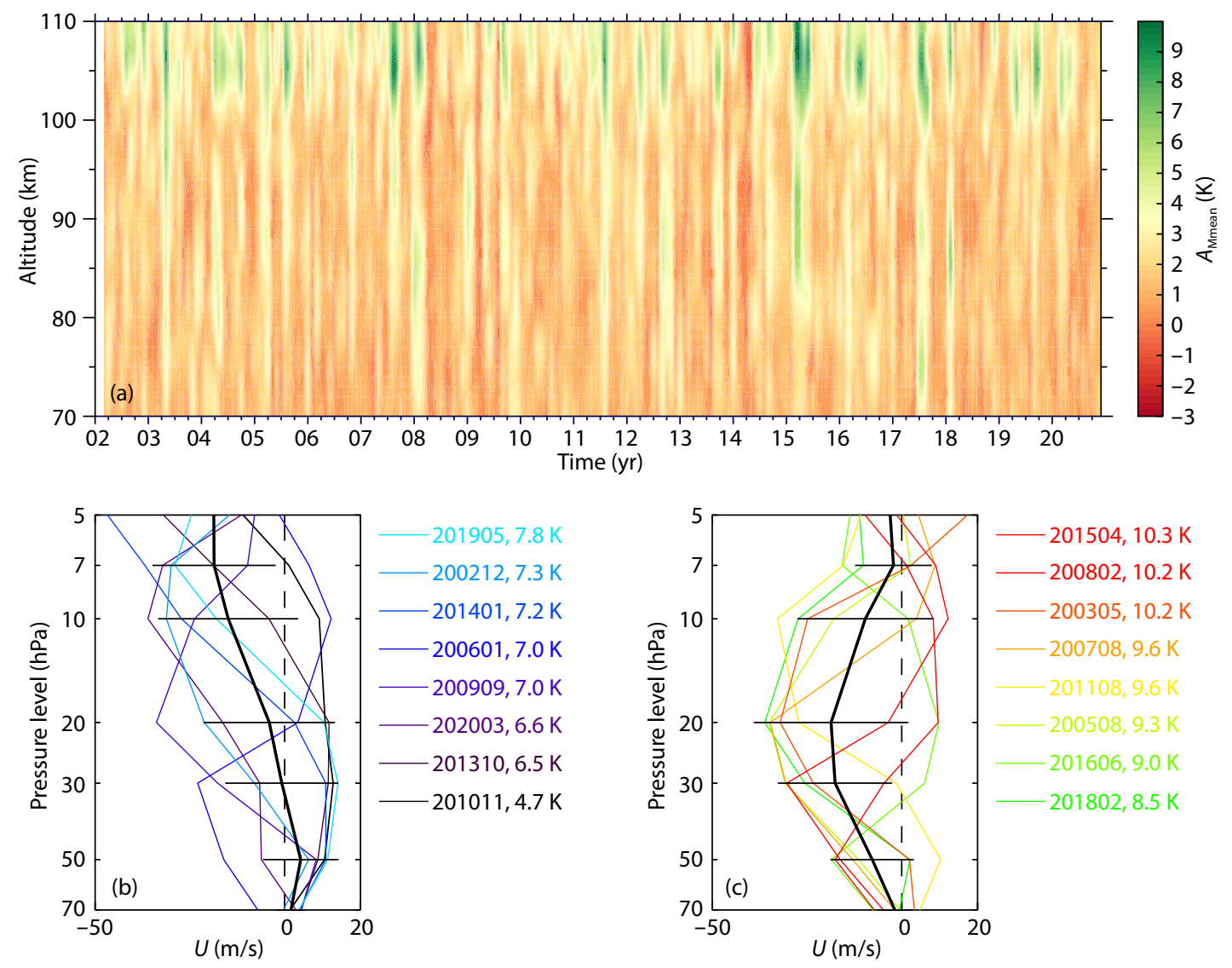

Figure 9. (a) For $30^{\circ} \mathrm{N}-50^{\circ} \mathrm{N}$, time-altitude section-averaged $A_{\mathrm{Mmax}}$ of $6.5 \mathrm{DWs}$. (b)/(c) Vertical profiles of QBO zonal wind, $U$, of the eight weakest/strongest annual maximums $A_{\mathrm{Mmax}}$. The $A_{\mathrm{Mmax}}$ and their corresponding months of occurrence are shown at the right side of each panel. Colors of the plots are in accordance with the caption.

Table 2. The annual maximums $A_{\mathrm{Mmax}}$ observed $30^{\circ} \mathrm{N}$ to $50^{\circ} \mathrm{N}$ at 70 to $110 \mathrm{~km}$ during $2002-2020$, months when they occur, and their ranks.

\begin{tabular}{ccccccccccccccccccccccc}
\hline Year & 2002 & 2003 & 2004 & 2005 & 2006 & 2007 & 2008 & 2009 & 2010 & 2011 & 2012 & 2013 & 2014 & 2015 & 2016 & 2017 & 2018 & 2019 & 2020 \\
\hline Ann. Max. (K) & 7.3 & 10.2 & 7.9 & 9.3 & 7.0 & 9.6 & 10.2 & 7.0 & 4.7 & 9.6 & 7.8 & 6.5 & 7.2 & 10.3 & 9.0 & 8.2 & 8.5 & 7.8 & 6.6 \\
Month & Dec. & May & Oct. & Aug. & Jan. & Aug. & Feb. & Sep. & Nov. & Aug. & Sep. & Oct. & Jan. & Apr. & Jun. & Aug. & Feb. & May & Mar. \\
Rank & 7 & 17 & 10 & 14 & 5 & 16 & 18 & 4 & 1 & 15 & 9 & 2 & 6 & 19 & 13 & 11 & 12 & 8 & 3 \\
\hline
\end{tabular}

ted $A_{\text {Mmax }}$ data.

Figure 9a shows that the 6.5DWs' $A_{\text {Mmax }}$ exhibit little temporal variation by altitude between $70-110 \mathrm{~km}$. It is clear from Figure $9 \mathrm{~b}$ and 9c that from 70 to $5 \mathrm{hPa}$, during 2002-2020, vertical trends of mean QBO (thick black curve) of the eight weakest annual maximum $A_{\text {Mmax }}$ cases (Figure 9b) were totally different from those of the eight strongest cases (Figure 9c). For the weak 6.5DW maxima 
(Figure 9b), the mean QBO wind (thick black curve) below $30 \mathrm{hPa}$ is seen to have been weak-westerly; at $70 \mathrm{hPa}$ it averaged $1.7 \mathrm{~m} / \mathrm{s}$; at $50 \mathrm{hPa}$ it averaged $4.2 \mathrm{~m} / \mathrm{s}$. Mean QBO wind at higher altitudes reversed to easterly, its strength increasing with altitude. From 70 to $5 \mathrm{hPa}, \mathrm{QBO}$ winds at all times of weak 6.5DW maximums turned from weak westerlies at $70 \mathrm{hPa}$ to easterlies at $5 \mathrm{hPa}$ through a slight acceleration of westerlies between 70 and $30 \mathrm{hPa}$, except easterly in January 2006, when the QBO wind was $7.1 \mathrm{~m} / \mathrm{s}$ easterly at $70 \mathrm{hPa}$, reversed to $3.5 \mathrm{~m} / \mathrm{s}$ westerly at $20 \mathrm{hPa}$, and turned back again to $1.4 \mathrm{~m} / \mathrm{s}$ easterly at $5 \mathrm{hPa}$.

At times of strong 6.5DW maximums, however, mean QBO wind was easterly at all levels from 70 to $5 \mathrm{hPa}$ (Figure 9c). The maximum QBO easterly was $18.7 \mathrm{~m} / \mathrm{s}$ at $20 \mathrm{hPa}$. QBO profiles of the eight strong maximum 6.5DW cases demonstrate more similarities between each other than was observed in the weak maximum 6.5DW cases. In general, QBO wind directions turned from easterlies or weak westerlies at lower levels to westerlies between 30 and $7 \mathrm{hPa}$. The westerlies could reverse to easterlies, except in August 2011 and February 2018. In addition, during June 2016, February 2008, and April 2015, when QBO winds had easterly maximums between $50-30 \mathrm{hPa}$ and reversed to westerlies at 30, 20, and $10 \mathrm{hPa}$, respectively, they turned back to easterlies again between 7-5 hPa.

Mean QBO profiles can provide general vertical trends for either strong or weak 6.5DWs cases, although vertical features of each QBO profile differ one from another. Former studies of possible correlations between planetary waves and QBO have used QBO wind speeds at $50 \mathrm{hPa}$ (Merzlyakov et al., 2013; Laskar et al., 2016; de Wit et al., 2016) or the speed differences between 70 and $10 \mathrm{hPa}$ (Miyoshi and Hirooka, 2003) as their indicator of QBO strength. From our statistical results, it seems reasonable to choose QBO wind at $50 \mathrm{hPa}$, because for both the strongest and the weakest 6.5DW situations, the standard deviation of QBO winds is the smallest at the $50 \mathrm{hPa}$ level. In the weak/strong instances of 6.5DW maximums, QBO winds at $50 \mathrm{hPa}$ were usually (in six/five cases) westerlies/easterlies. However, we do note significant exceptions e.g., weak cases in January 2006 and March 2020 when the QBO at $50 \mathrm{hPa}$ was easterly, and strong cases in May 2003, August 2011, and February 2018 when the QBO at $50 \mathrm{hPa}$ was westerly. As a result, more statistical analysis of data collected over a longer time span is needed to provide more evidence that might lead to a better indicator of QBO influence on atmospheric wave activities.

Figure 10 and Table 3 show results similar to those presented in Figure 9 and Table 2, respectively, but for $30^{\circ} \mathrm{S}-50^{\circ} \mathrm{S}$. Figure 10a shows obvious annual maximums $A_{\text {Mmax }}$ below $100 \mathrm{~km}$ in February 2009, October 2012, April 2015, and September 2019, when dominant annual maximums $A_{M \max }$ also emerge above $100 \mathrm{~km}$.
Mean QBO winds (Figure 10b) were weak westerlies below $50 \mathrm{hPa}$, $2.4 \mathrm{~m} / \mathrm{s}$ at $70 \mathrm{hPa}$, and $1.3 \mathrm{~m} / \mathrm{s}$ at $50 \mathrm{hPa}$. Above $50 \mathrm{hPa}$, the speed of QBO easterlies increased with altitude reaching $-26.8 \mathrm{~m} / \mathrm{s}$ at $10 \mathrm{hPa}$. From 10 to $5 \mathrm{hPa}$ they decreased slightly to $-22.3 \mathrm{~m} / \mathrm{s}$ at $7 \mathrm{hPa}$ and $-21.9 \mathrm{~m} / \mathrm{s}$ at $5 \mathrm{hPa}$. All QBO profiles at times of weak $6.5 \mathrm{DW}$ maximums in the $30^{\circ} \mathrm{S}-50^{\circ} \mathrm{S}$ region exhibit more similarities with each other than do weak 6.5DWs' maximums in the $\mathrm{NH}$ (Figure 9b). QBO winds at $50 \mathrm{hPa}$ were weak in both directions in all years of weak 6.5DW maximums. The largest absolute zonal wind speed reached $11.4 \mathrm{~m} / \mathrm{s}$ westward at August 2005. QBO winds were easterlies at and above the $30 \mathrm{hPa}$ altitude, with these four westerly exceptions: at $30 \mathrm{hPa}, 8.2 \mathrm{~m} / \mathrm{s}$ in February 2011; at $20 \mathrm{hPa}, 3.7 \mathrm{~m} / \mathrm{s}$ in February 2011 and $8.6 \mathrm{~m} / \mathrm{s}$ in March 2016; at $7 \mathrm{hPa}, 2.3 \mathrm{~m} / \mathrm{s}$ in August 2005.

Vertical variations of QBO wind profiles differ more from each other when 6.5DW activities are strong in $30^{\circ} \mathrm{S}-50^{\circ} \mathrm{S}$ (Figure 10c) than when they are weak (Figure 10b): at $70 \mathrm{hPa}$, the mean QBO wind is weak $(0.3 \mathrm{~m} / \mathrm{s})$ and westerly; at all altitudes above $70 \mathrm{hPa}$, the wind is easterly, from $2.4-18.3 \mathrm{~m} / \mathrm{s}$, the latter reached at $5 \mathrm{hPa}$. From 50 to $5 \mathrm{hPa}$, the speed of the easterlies increases with altitude generally to $18.3 \mathrm{~m} / \mathrm{s}$ at $5 \mathrm{hPa}$, with slight decreasing to $5.3 \mathrm{~m} / \mathrm{s}$ around $20 \mathrm{hPa}$. In April 2015 and October 2012 when $A_{\mathrm{Mmax}}$ were the strongest during 2002-2020, QBO easterly winds rose above $30.3 \mathrm{~m} / \mathrm{s}$ at $30 \mathrm{hPa}$ and westerlies at $10 \mathrm{hPa}$ sped up to more than $12.2 \mathrm{~m} / \mathrm{s}$.

From comparisons between 6.5DWs strengths and QBO profiles, vertical QBO profiles show patterns of similarity with each other at the strongest/weakest 6.5DWs maximums in the $\mathrm{NH}$ (Figure 9c/ Figure 9b), and the weakest maximums in the SH (Figure 10b). These results indicate that QBO profiles from 70 to $5 \mathrm{hPa}$ appear to influence $6.5 \mathrm{DW}$ activity in MLT regions of the $30^{\circ}-50^{\circ}$ latitude bands in both hemispheres.

\subsection{Correlation Coefficients Between $\boldsymbol{A}_{\mathrm{Mmax}}$ and $\boldsymbol{P}_{\mathrm{QBO}}$}

To represent vertical characteristics of whole $\mathrm{QBO}$ profiles quantitatively, $\mathrm{QBO}$ phase, $P_{\mathrm{QBO}}$, is defined by empirical orthogonal functions (EOFs) (Fraedrich et al., 1993; Wallace et al., 1993; Anstey et al., 2010; Solomon et al., 2014). In this study, $P_{\mathrm{QBO}}$ is calculated based on monthly mean zonal averaged zonal wind from 70 to $5 \mathrm{hPa}$ between $5^{\circ} \mathrm{S} / \mathrm{N}$ from January 2002 to December 2020, using the method introduced by Fraedrich et al. (1993) and Wallace et al. (1993).

Linear Pearson correlation coefficients between $P_{\mathrm{QBO}}$ and $A_{\mathrm{Mmax}}$ for each month are calculated as the covariance between them. Seasonal variations show that 6.5DWs in MLT region usually have considerable amplitudes during April and August in the $\mathrm{NH}$, and during February and November in the SH. Results of these four months are demonstrated in Figure 11. Colored cell-fill contours

Table 3. Similar to Table 2 , but for observations at $30^{\circ} \mathrm{S}-50^{\circ} \mathrm{S}$.

\begin{tabular}{ccccccccccccccccccccc}
\hline Year & 2002 & 2003 & 2004 & 2005 & 2006 & 2007 & 2008 & 2009 & 2010 & 2011 & 2012 & 2013 & 2014 & 2015 & 2016 & 2017 & 2018 & 2019 & 2020 \\
\hline Ann. Max. (K) & 7.3 & 6.7 & 8.0 & 5.8 & 7.7 & 6.8 & 8.6 & 8.6 & 6.0 & 6.8 & 9.4 & 7.8 & 8.5 & 9.6 & 6.2 & 7.6 & 6.0 & 8.7 & 4.6 \\
Month & Dec. & Mar. & Oct. & Aug. & Nov. & Feb. & Jan. & Feb. & Mar. & Feb. & Oct. & Sep. & Oct. & Apr. & Mar. & Aug. & Feb. & Sep. & Jan. \\
Rank & 9 & 6 & 13 & 2 & 11 & 7 & 16 & 15 & 3 & 8 & 18 & 12 & 14 & 19 & 5 & 10 & 4 & 17 & 1 \\
\hline
\end{tabular}



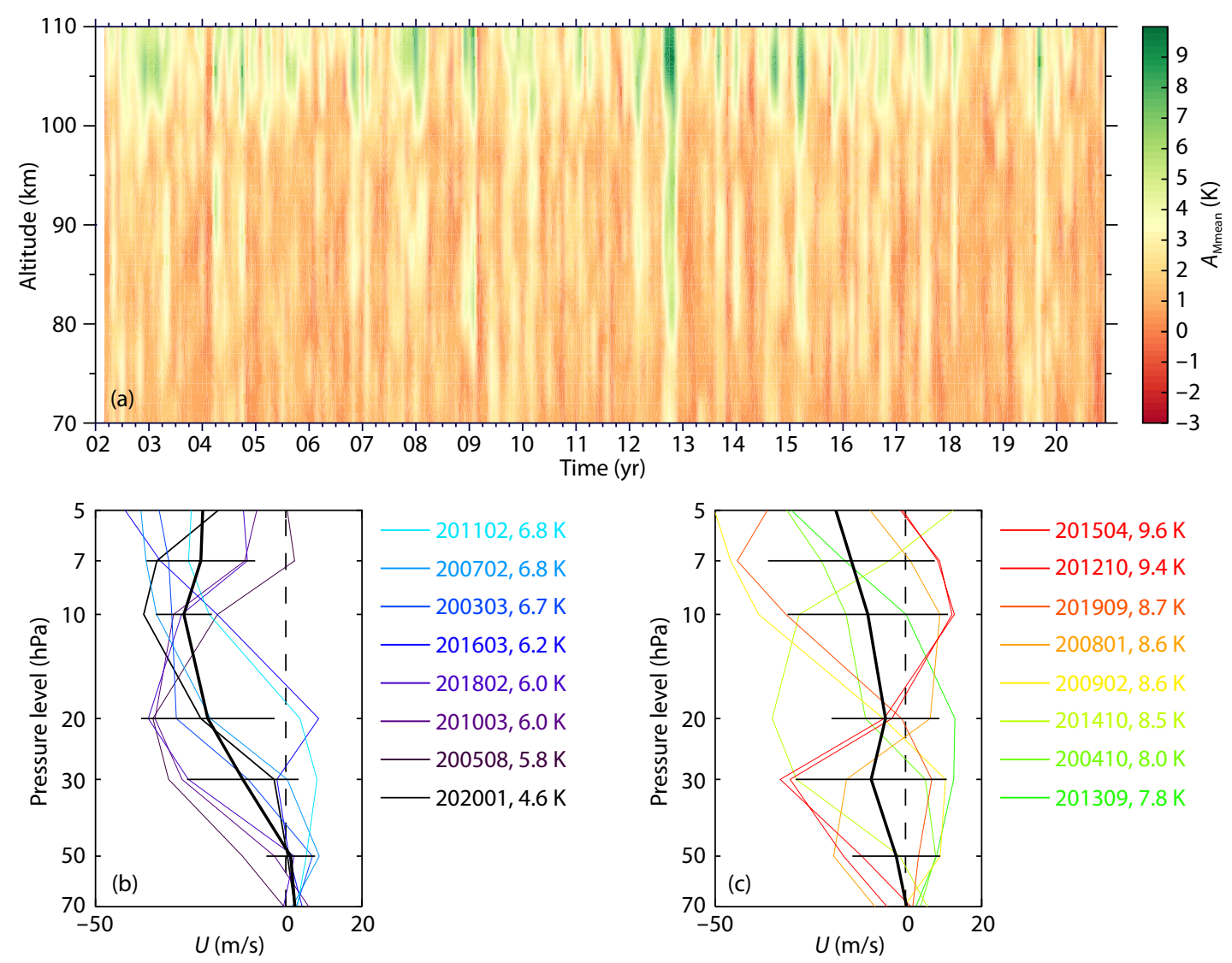

Figure 10. Results similar to those of Figure 9 , but for $6.5 \mathrm{DW}$ amplitudes observed at $30^{\circ} \mathrm{S}-50^{\circ} \mathrm{S}$.
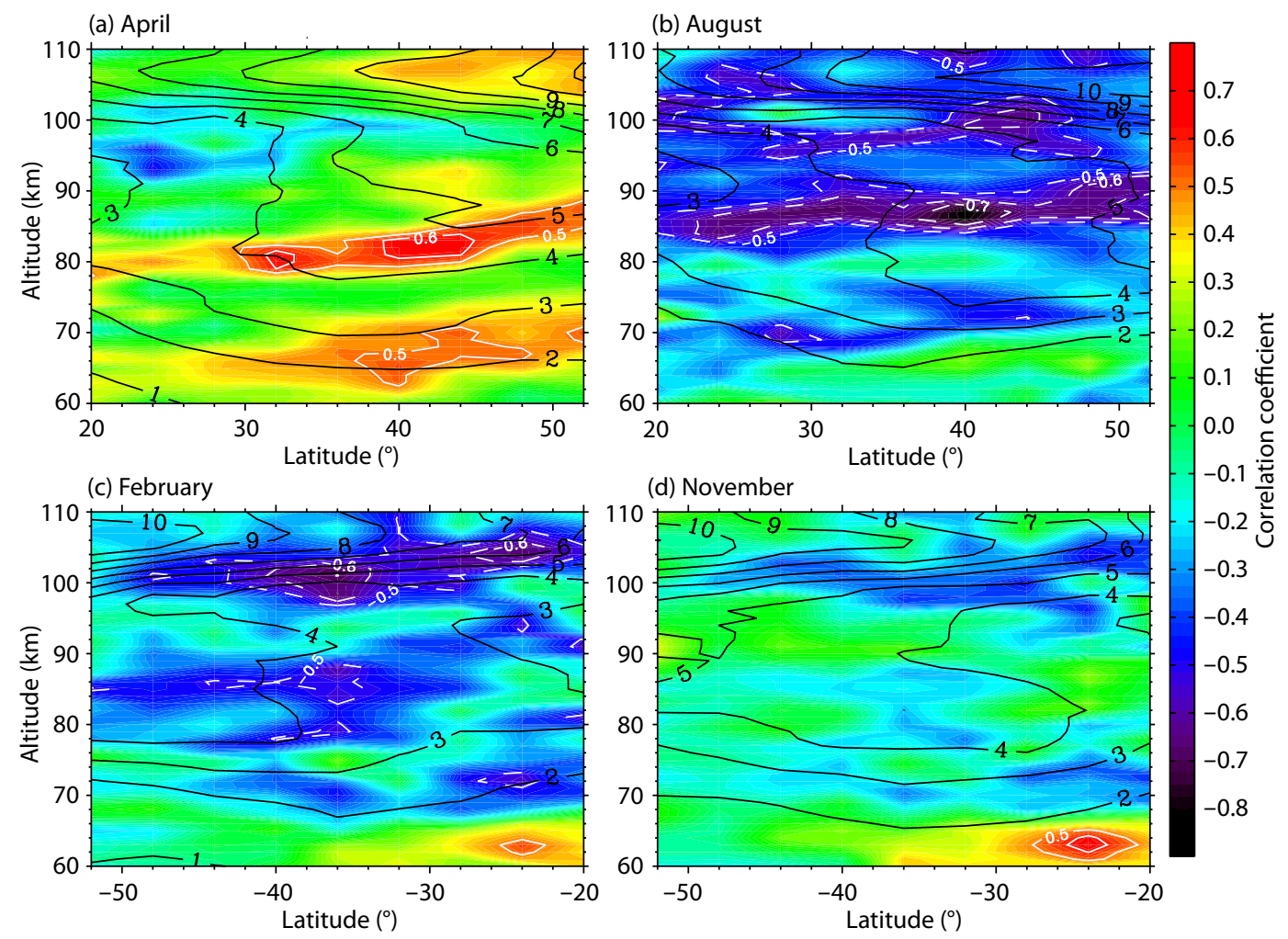

Figure 11. Latitude-altitude distributions of linear Pearson correlation coefficients between $P_{\mathrm{QBO}}$ and $A_{\mathrm{Mmax}}$ (colored cell-filled contours). White solid and dashed contours represent correlations of 0.6 and -0.6 , respectively. Black contours represent 2002-2020 averaged $A_{\text {Mmax }}$. Panels (a) and (b) show results between $20^{\circ} \mathrm{N}-52^{\circ} \mathrm{N}$ in April and August, respectively; Panels (c) and (d) show results between $20^{\circ} \mathrm{S}-52^{\circ} \mathrm{S}$ in February and November, respectively. 
show linear Pearson correlation coefficients of $P_{\mathrm{QBO}}$ and $A_{\mathrm{Mmax}}$. Overplotted white solid and dashed contours indicate correlations of 0.6 and -0.6 , respectively. Black solid contours indicate 2002-2020 averaged 6.5DW $A_{\text {Mmax }}$. Panels (a), (b), (c), and (d) demonstrate correlation results in April and August in $20^{\circ} \mathrm{N}-52^{\circ} \mathrm{N}$ and February and November in $20^{\circ} \mathrm{S}-52^{\circ} \mathrm{S}$, respectively.

In April (Figure 11a), the correlation is generally positive at 60$110 \mathrm{~km}$ between $20^{\circ} \mathrm{N}-52^{\circ} \mathrm{N}$. It is greater than 0.5 in two regions: a stronger belt at higher altitude near $78-85 \mathrm{~km}$ from $30^{\circ} \mathrm{N}$ to $52^{\circ} \mathrm{N}$, and a weaker belt around $63-70 \mathrm{~km}$ from $36^{\circ} \mathrm{N}$ to $48^{\circ} \mathrm{N}$. The greatest positive correlation is 0.64 around $80 \mathrm{~km}$ at $32^{\circ} \mathrm{N}$ and $82 \mathrm{~km}$ between $40^{\circ} \mathrm{N}$ and $44^{\circ} \mathrm{N}$. The maximum wave $A_{\mathrm{Mmax}}$ appears around $105 \mathrm{~km}$ poleward from $48^{\circ} \mathrm{N}$, where the correlation is weakly positive. In August (Figure 11b), the correlation is almost uniformly negative from 80 to $110 \mathrm{~km}$ between $20^{\circ} \mathrm{N}-50^{\circ} \mathrm{N}$. There are also two strong negative belts: a stronger belt near $84-92 \mathrm{~km}$ between $20^{\circ} \mathrm{N}-50^{\circ} \mathrm{N}$ and a relative weaker belt near $94-102 \mathrm{~km}$ from $20^{\circ} \mathrm{N}-48^{\circ} \mathrm{N}$. The maximum negative correlation is -0.83 around $88 \mathrm{~km}$ at $40^{\circ} \mathrm{N}$. Large negative correlation coefficient $<-0.6$ ) appears around $85-92 \mathrm{~km}$ from $32^{\circ} \mathrm{N}$ to $52^{\circ} \mathrm{N}$ and around $100 \mathrm{~km}$ between $40^{\circ} \mathrm{N}$ and $44^{\circ} \mathrm{N}$. These two belts demonstrate meridional expansion of QBO's impact on 6.5DW activities in the MLT region at mid-latitudes in the $\mathrm{NH}$. At regions of maximum 6.5DW activity around $95 \mathrm{~km}$ poleward from $40^{\circ} \mathrm{N}$, the correlation is weakly positive/negative during April/August. During these months, peak altitude levels and latitude bands are similar, though the direction of the correlation is opposite.

Correlation during February and November between $20^{\circ} \mathrm{S}-52^{\circ} \mathrm{S}$ is generally weaker than that during April and August in the $\mathrm{NH}$. In February, strong positive correlations appear around $64 \mathrm{~km}$ at $24^{\circ} \mathrm{S}$, while strong negative correlations are observed around 96-106 km between $20^{\circ} \mathrm{S}-44^{\circ} \mathrm{S}$. In November, correlations are generally weak, except a positive maximum appearing near $61-66 \mathrm{~km}$ around $20^{\circ} \mathrm{S}-28^{\circ} \mathrm{S}$. This maximum region is the same as in February. There are also regions of negative correlation around $96-106 \mathrm{~km}$ between $20^{\circ} \mathrm{S}-44^{\circ} \mathrm{S}$, as in February, but with weaker values.

\section{Discussion}

In previous studies of possible relationship between the QBO and long-term variations of atmospheric waves, QBO phases have usually been defined by zonal wind directions at a single pressure level, mostly at $50 \mathrm{hPa}$ (Holton and Tan HC, 1980; Merzlyakov et al., 2013, 2015; de Wit et al., 2016; Laskar et al., 2016), or the vertical shear of QBO wind, e.g., between 70 and $10 \mathrm{hPa}$ (Miyoshi and Hirooka, 2003). Moreover, most previous results have been qualitative, and thus insufficient to support theoretical studies intended to identify mechanisms of QBO modulation of atmospheric waves. This study was motivated by the need for sufficient additional observational evidence to establish quantitatively valid correlations between the vertical structure of the QBO and inter-annual variations of waves.

Both wavelet analytical results and linear Pearson correlation coefficients obtained in this study confirm QBO signals in long-term variations of MLT $6.5 \mathrm{DWs}$ at $30^{\circ}-50^{\circ}$ latitude bands in both hemispheres. These results provide credible evidence of QBO modula- tion of 6.5DWs.

The QBO may be able to modulate both the generation and propagation processes of the 6.5DWs. In the MLT region, $6.5 \mathrm{DWs}$ originate in inter-hemispheric propagations (Riggin et al., 2006; Merzlyakov et al., 2013) and nonlinear interactions between 7-day waves and stationary planetary waves 1 (SPW1) (Kishore et al., 2004). As the HT effect proposed, inter-hemispheric propagation of SPW1 from the winter to summer hemisphere can be modulated by the equatorial QBO. So the QBO may impact the generation processes of 6.5DWs secondarily. These processes have been proposed as a potential mechanism for QBO modulation of semidiurnal tides (Laskar et al., 2016). More studies are needed to examine whether this is also the way that the QBO modulates 6.5DWs. Our results should encourage further assembly of observational data relevant to these questions.

\section{Conclusions}

In this paper, inter-annual variations of 6.5DWs and their correlations with the QBO have been studied. To remove annual variations in the 6.5DWs, residual 6.5DW amplitudes were calculated and taken to be representative of wave strengths (Figure 5). Wavelet analysis was performed on 15-day-averaged 6.5DW amplitudes. The results show clear spectral peaks around QBO periods in the $32^{\circ}-48^{\circ}$ latitude bands of both hemispheres (Figure 6-8). Peak periods in the $\mathrm{NH}$ are around $28-38$ months, longer than the 24-30 months observed in the $\mathrm{SH}$. Also, peak periods lengthen poleward in the $\mathrm{NH}$ but are unchanged with latitude in the $\mathrm{SH}$.

Comparisons between 6.5DWs' $A_{\mathrm{Mmax}}$ and vertical profiles of the $\mathrm{QBO}$ from 70 to $5 \mathrm{hPa}$ indicate clear correlations between the QBO and 6.5DWs in both hemispheres, but stronger in the $\mathrm{NH}$. When an $A_{\text {Mmax }}$ is large, the corresponding mean QBO profile is easterly at all levels from 70 to $5 \mathrm{hPa}$ (Figure 9c); when it is weak, the mean $\mathrm{QBO}$ wind is weak westerly below $30 \mathrm{hPa}$ (Figure 9b).

Linear Pearson correlation coefficients between $P_{\mathrm{QBO}}$ and $A_{\mathrm{Mmax}}$ (Figure 11) show large positive values from $60-110 \mathrm{~km}$ between $20^{\circ} \mathrm{N}-52^{\circ} \mathrm{N}$ in April, and large negative values from 80 to $110 \mathrm{~km}$ between $20^{\circ} \mathrm{N}-50^{\circ} \mathrm{N}$ in August. Correlation coefficient during February and November between $20^{\circ} \mathrm{S}-52^{\circ} \mathrm{S}$ is generally weaker than that during April and August in the $\mathrm{NH}$. In February, strong positive relativities appear around $64 \mathrm{~km}$ at $24^{\circ} \mathrm{S}$, while strong negative correlation coefficient appears around 96-106 km between $20^{\circ} \mathrm{S}-44^{\circ} \mathrm{S}$.

Results obtained in this paper indicate quantitative correlations between the QBO and 6.5DWs; we suggest that these correlations are credible evidence of QBO modulation of long-term variations of the 6.5DWs. However, more observation and model studies are needed to further elucidate these complex geophysical processes.

\section{Acknowledgments}

This work is jointly supported by the National Basic Research Program of China through grant 2012CB825606; the National Natural Science Foundation of China through grants 41504118, 41375045, 41525015, and 41774186; the Natural Science Foundation of Jiangsu Province through grants BK20150709 and BK20161531; and Projects Supported by the Specialized Research Fund for State Key 
Laboratories. Websites of data used are at http://saber.gats-inc. com/data.php and https://apps.ecmwf.int/data-catalogues/era5/? class=ea. The authors acknowledge the efforts of the TIMED/ SABER team in making the data available and freely downloadable.

\section{References}

Anstey, J. A., Shepherd, T. G., and Scinocca, J. F. (2010). Influence of the quasibiennial oscillation on the extratropical winter stratosphere in an atmospheric general circulation model and in reanalysis data. J. Atmos. Sci., 67(5), 1402-1419. https://doi.org/10.1175/2009jas3292.1

Anstey, J. A., and Shepherd, T. G. (2014). High-latitude influence of the quasibiennial oscillation. Quart. J. Roy. Meteor. Soc., 140(678), 1-21. https://doi.org/10.1002/qj.2132

Bai, X. Y., Huang, K. M., Zhang, S. D., Huang, C. M. and Gong, Y. (2021). Anomalous changes of temperature and ozone QBOs in 2015-2017 from radiosonde observation and MERRA-2 reanalysis. Earth Planet. Phys., 5(3), 280-289. https://doi.org/10.26464/epp2021028

Balachandran, N. K., and Rind, D. (1995). Modeling the effects of UV variability and the QBO on the troposphere-stratosphere system. Part I: the middle atmosphere. J. Climate, 8(8), 2058-2079. https://doi.org/10.1175/15200442(1995)008<2058:MTEOUV>2.0.CO;2

Baldwin, M. P., and Dunkerton, T. J. (1989). Observations and statistical simulations of a proposed solar cycle/QBO/weather relationship. Geophys. Res. Lett., 16(8), 863-866. https://doi.org/10.1029/GL016i008p00863

Baldwin, M. P., Gray, L. J., Dunkerton, T. J., Hamilton, K., Haynes, P. H., Randel, W. J., Holton, J. R., Alexander, M. J., Hirota, I., ... Takahashi, M. (2001). The quasibiennial oscillation. Rev. Geophys., 39(2), 179-229. https://doi.org/10.1029/1999RG000073

Belova, A., Kirkwood, S., Murtagh, D., Mitchell, N., Singer, W., and Hocking, W. (2008). Five-day planetary waves in the middle atmosphere from Odin satellite data and ground-based instruments in Northern Hemisphere summer 2003, 2004, 2005 and 2007. Ann. Geophys., 26(11), 3557-3570. https://doi.org/10.5194/angeo-26-3557-2008

Boville, B. A. (1984). The influence of the polar night jet on the tropospheric circulation in a GCM. J. Atmos. Sci., 41(7), 1132-1142. https://doi.org/10.1175/1520-0469(1984)041<1132:TIOTPN>2.0.CO;2

Day, K. A., Taylor, M. J., and Mitchell, N. J. (2012). Mean winds, temperatures and the 16- and 5-day planetary waves in the mesosphere and lower thermosphere over Bear Lake Observatory ( $\left.42^{\circ} \mathrm{N}, 111^{\circ} \mathrm{W}\right)$. Atmos. Chem. Phys., 12(3), 1571-1585. https://doi.org/10.5194/acp-12-1571-2012

de Wit, R. J., Janches, D., Fritts, D. C., and Hibbins, R. E. (2016). QBO modulation of the mesopause gravity wave momentum flux over Tierra del Fuego. Geophys. Res. Lett., 43(8), 4049-4055. https://doi.org/10.1002/2016gl068599

Fraedrich, K., Pawson, S., and Wang, R. S. (1993). An EOF analysis of the verticaltime delay structure of the quasi-biennial oscillation. J. Atmos. Sci., 50(20), 3357-3365. https://doi.org/10.1175/1520-0469(1993)050<3357:AEAOTV> 2.0.CO;2

Gan, Q., Yue, J., Chang, L. C., Wang, W. B., Zhang, S. D., and Du, J. (2015). Observations of thermosphere and ionosphere changes due to the dissipative 6.5-day wave in the lower thermosphere. Ann. Geophys., 33(7), 913-922. https://doi.org/10.5194/angeo-33-913-2015

García-Comas, M., López-Puertas, M., Marshall, B. T., Wintersteiner, P. P., Funke, B., Bermejo-Pantaleón, D., Mertens, C. J., Remsberg, E. E., Gordley, L. L., ... Russell III, J. M. (2008). Errors in sounding of the atmosphere using broadband emission radiometry (SABER) kinetic temperature caused by non-local-thermodynamic-equilibrium model parameters. J. Geophys. Res.: Atmos., 113(D24), D24106. https://doi.org/10.1029/2008jd010105

Garfinkel, C. I., Shaw, T. A., Hartmann, D. L., and Waugh, D. W. (2012). Does the holton-tan mechanism explain how the quasi-biennial oscillation modulates the arctic polar vortex?. J. Atmos. Sci., 69(5), 1713-1733. https://doi.org/10.1175/jas-d-11-0209.1

Gray, L. J., Phipps, S. J., Dunkerton, T. J., Baldwin, M. P., Drysdale, E. F., and Allen, M. R. (2001). A data study of the influence of the equatorial upper stratosphere on northern-hemisphere stratospheric sudden warmings. Quart. J. Roy. Meteor. Soc., 127(576), 1985-2003.

https://doi.org/10.1002/qj.49712757607

Gu, S. Y., Ruan, H. B., Yang, C. Y., Gan, Q., Dou, X. K., and Wang, N. N. (2018). The morphology of the 6-day wave in both the neutral atmosphere and f region ionosphere under solar minimum conditions. J. Geophys. Res.: Space Phys., 123(5), 4232-4240. https://doi.org/10.1029/2018ja025302

Gu, S. Y., Dou, X. K., Yang, C. Y., Jia, M. J., Huang, K. M., Huang, C. M., and Zhang, S. D. (2019). Climatology and anomaly of the quasi-two-day wave behaviors during 2003-2018 austral summer periods. J. Geophys. Res.: Space Phys., 124(1), 544-556. https://doi.org/10.1029/2018ja026047

Hersbach, H., Bell, B., Berrisford, P., Hirahara, S., Horányi, A., Muñoz-Sabater, J., Nicolas, J., Peubey, C., Radu, R., ...Thépaut, J. N. (2020). The ERA5 global reanalysis. Quart. J. Roy. Meteor. Soc., 146(730), 1999-2049. https://doi.org/10.1002/qj.3803

Holton, J. R., and Tan, H. C. (1980). The influence of the equatorial quasibiennial oscillation on the global circulation at $50 \mathrm{mb}$. J. Atmos. Sci., 37(10), 2200-2208. https://doi.org/10.1175/1520-0469(1980)037<2200:TIOTEQ> 2.0.CO;2

Huang, Y. Y., Zhang, S. D., Yi, F., Huang, C. M., Huang, K. M., Gan, Q., and Gong, Y. (2013). Global climatological variability of quasi-two-day waves revealed by TIMED/SABER observations. Ann. Geophys., 31(6), 1061-1075. https://doi.org/10.5194/angeo-31-1061-2013

Huang, Y. Y., Zhang, S. D., Li, C. Y., Li, H. J., Huang, K. M., and Huang, C. M. (2017). Annual and interannual variations in global 6.5DWs from 20 to $110 \mathrm{~km}$ during 2002-2016 observed by TIMED/SABER. J. Geophys. Res. :Space Phys., 122(8), 8985-9002. https://doi.org/10.1002/2017ja023886

Jiang, G., Xu, J. Y., Xiong, J., Ma, R., Ning, B., Murayama, Y., Thorsen, D., Gurubaran, S., Vincent, R. A., and Reid, I. (2008a). A case study of the mesospheric 6.5-day wave observed by radar systems. J. Geophys. Res. Atmos., 113(D16), D16111. https://doi.org/10.1029/2008JD009907

Jiang, G., Xiong, J., Wan, W., Ning, B., and Liu, L. (2008b). Observation of 6.5-day waves in the MLT region over Wuhan. J. Atmos. Sol. Terr. Phys., 70(1), 41-48. https://doi.org/10.1016/j.jastp.2007.09.008

John, S. R., and Kumar, K. K. (2012). TIMED/SABER observations of global gravity wave climatology and their interannual variability from stratosphere to mesosphere lower thermosphere. Climate Dyn., 39(6), 1489-1505. https://doi.org/10.1007/s00382-012-1329-9

Kim, Y. H., and Chun, H. Y. (2015). Contributions of equatorial wave modes and parameterized gravity waves to the tropical QBO in HadGEM2. J. Geophys. Res.: Atmos., 120(3), 1065-1090. https://doi.org/10.1002/2014jd022174

Kishore, P., Namboothiri, S. P., Igarashi, K., Gurubaran, S., Sridharan, S., Rajaram, R., and Ratnam, M. V. (2004). MF radar observations of 6.5-day wave in the equatorial mesosphere and lower thermosphere. J. Atmos. Sol. Terr. Phys., 66(6-9), 507-515. https://doi.org/10.1016/j.jastp.2004.01.026

Laskar, F. I., Chau, J. L., Stober, G., Hoffmann, P., Hall, C. M., and Tsutsumi, M. (2016). Quasi-Biennial Oscillation Modulation of the Middle- and HighLatitude Mesospheric Semidiurnal Tides During August-September. J. Geophys. Res. :Space Phys., 121(5), 4869-4879. https://doi.org/10.1002/2015ja022065

Li, T., She, C. Y., Palo, S. E., Wu, Q., Liu, H. L., and Salby, M. L. (2008). Coordinated lidar and TIMED observations of the quasi-two-day wave during August 2002-2004 and possible quasi-biennial oscillation influence. Adv. Space Res., 41(9), 1463-1471. https://doi.org/10.1016/j.asr.2007.03.052

Li, X., Wan, W. X., Ren, Z. P., Liu, L. B., and Ning, B. Q. (2015). The variability of nonmigrating tides detected from TIMED/SABER observations. J. Geophys. Res. :Space Phys., 120(12), 10793-10808. https://doi.org/10.1002/2015ja021577

Li, X., Wan, W. X., Cao, J. B., and Ren, Z. P. (2020). Wavenumber-4 spectral component extracted from TIMED/SABER observations. Earth Planet. Phys., 4(5), 436-448. https://doi.org/10.26464/epp2020040

Li, Y., Sheng Z., and Jing, J. R. (2019). Feature analysis of stratospheric wind and temperature fields over the Antigua site rocket data. Earth Planet. Phys., 3(5), 414-424. https://doi.org/10.26464/epp2019040

Lima, L. M., Batista, P. P., Clemesha, B. R., and Takahashi, H. (2005). The 6.5-day oscillations observed in meteor winds over Cachoeira Paulista $\left(22.7^{\circ} \mathrm{S}\right)$. Adv. 
Space Res., 36(11), 2212-2217. https://doi.org/10.1016/j.asr.2005.06.005

Lin, P., Held, I., and Ming, Y. (2019). The early development of the 2015/16 quasi-biennial oscillation disruption. J. Atmos. Sci, 76(3), 821-836. https://doi.org/10.1175/jas-d-18-0292.1

Liu, H. L., Talaat, E. R., Roble, R. G., Lieberman, R. S., Riggin, D. M., and Yee, J. H. (2004). The 6.5-day wave and its seasonal variability in the middle and upper atmosphere. J. Geophys. Res. :Atmos., 109(D21), D21112. https://doi.org/10.1029/2004jd004795

Liu, M. H., Xu, J. Y., Liu, H. L., and Liu, X. (2016). Possible modulation of migrating diurnal tide by latitudinal gradient of zonal wind observed by SABER/TIMED. Sci. China Earth Sci., 59(2), 408-417. https://doi.org/10.1007/s11430-015-5185-4

Liu, X., Xu, J. Y., and Yue, J. (2020). Global static stability and its relation to gravity waves in the middle atmosphere. Earth Planet. Phys., 4(5), 504-512. https://doi.org/10.26464/epp2020047

Merkel, A. W., Thomas, G. E., Palo, S. E., and Bailey, S. M. (2003). Observations of the 5-day planetary wave in PMC measurements from the Student Nitric Oxide Explorer Satellite. Geophys. Res. Lett., 30(4), 1196. https://doi.org/10.1029/2002gl016524

Merzlyakov, E. G., Solovjova, T. V., and Yudakov, A. A. (2013). The interannual variability of a 5-7 day wave in the middle atmosphere in autumn from ERA product data, Aura MLS data, and meteor wind data. J. Atmos. Sol. Terr. Phys., 102, 281-289. https://doi.org/10.1016/j.jastp.2013.06.008

Merzlyakov, E. G., Jacobi, C., and Solovjova, T. V. (2015). The year-to-year variability of the autumn transition dates in the mesosphere/lower thermosphere wind regime and its coupling with the dynamics of the stratosphere and troposphere. J. Atmos. Sol. Terr. Phys., 122, 9-17. https://doi.org/10.1016/j.jastp.2014.11.002

Meyer, C. K., and Forbes, J. M. (1997). A 6.5-day westward propagating planetary wave: origin and characteristics. J. Geophys. Res. :Atmos., 102(D22), 26173-26178. https://doi.org/10.1029/97jd01464

Miyoshi, Y., and Hirooka, T. (2003). Quasi-biennial variation of the 5-day wave in the stratosphere. J. Geophys. Res.: Atmos., 108(D19), 4620. https://doi.org/10.1029/2002jd003145

Newman, P. A., Coy, L., Pawson, S., and Lait, L. R. (2016). The anomalous change in the QBO in 2015-2016. Geophys. Res. Lett., 43(16), 8791-8797. https://doi.org/10.1002/2016gl070373

Pancheva, D., Mukhtarov, P., Andonov, B., and Forbes, J. M. (2010). Global distribution and climatological features of the 5-6-day planetary waves seen in the SABER/TIMED temperatures. (2002-2007). J. Atmos. Sol. Terr. Phys., 72(1), 26-37. https://doi.org/10.1016/j.jastp.2009.10.005

Pancheva, D., Mukhtarov, P., and Siskind, D. E. (2018). Climatology of the quasi2-day waves observed in the MLS/Aura measurements (2005-2014). J. Atmos. Sol. Terr. Phys., 171, 210-224. https://doi.org/10.1016/j.jastp. 2017.05.002

Qin, Y. S., Gu, S. Y., Teng, C. K. M., Dou, X. K., Yu, Y., and Li, N. (2021). Comprehensive study of the climatology of the quasi-6-day wave in the MLT region based on aura/MLS observations and SD-WACCM-X simulations. J. Geophys. Res.: Space Phys., 126(1), e2020JA028454. https://doi.org/10.1029/2020ja028454

Rao, J., Yu, Y. Y., Guo, D., Shi, C. H., Chen, D., and Hu, D. Z. (2019). Evaluating the Brewer-Dobson circulation and its responses to ENSO, QBO, and the solar cycle in different reanalyses. Earth Planet. Phys., 3(2), 166-181. https://doi.org/10.26464/epp2019012

Reed, R. J., Campbell, W. J., Rasmussen, L. A., and Rogers, D. G. (1961). Evidence of a downward-propagating, annual wind reversal in the equatorial stratosphere. J. Geophys. Res., 66(3), 813-818. https://doi.org/10.1029/ JZ066i003p00813

Rezac, L. , Kutepov, A. , Russell III, J. M. , Feofilov, A. G. , Yue, J. , and Goldberg, R. A. (2015). Simultaneous retrieval of $T(p)$ and $\mathrm{CO}_{2}$ VMR from two-channel
non-LTE limb radiances and application to daytime SABER/TIMED measurements. J. Atmos. Sol. Terr. Phys. , 130-131, 23-42.

https://doi.org/10.1016/j.jastp.2015.05.004

Riggin, D. M., Liu, H. L., Lieberman, R. S., Roble, R. G., Russell III, J. M., Mertens, C. J., Mlynczak, M. G., Pancheva, D., Franke, S. J., ... Vincent, R. A. (2006). Observations of the 5-day wave in the mesosphere and lower thermosphere. J. Atmos. Sol. Terr. Phys., 68(3-5), 323-339. https://doi.org/10.1016/j.jastp.2005.05.010

Shuai, J., Zhang, S. D., Huang, C. M., Yi, F., Huang, K. M., Gan, Q., and Gong, Y. (2014). Climatology of global gravity wave activity and dissipation revealed by SABER/TIMED temperature observations. Sci. China Technol. Sci., 57(5), 998-1009. https://doi.org/10.1007/s11431-014-5527-z

Simmons, A. , Soci, C. , Nicolas, J. , Bell, B. , Berrisford, P. , Dragani, R. , Flemming, J. , Haimberger, L. , Healy, S. , ... Schepers, D. (2020). Global stratospheric temperature bias and other stratospheric aspects of ERA5 and ERA5.1. Technical Memorandum 859, Reading, UK: ECMWF. https://doi.org/10.21957/rcxqfmg

Solomon, A., Richter, J. H., and Bacmeister, J. T. (2014). An objective analysis of the QBO in ERA-Interim and the Community Atmosphere Model, version 5. Geophys. Res. Lett., 41(22), 7791-7798. https://doi.org/10.1002/ 2014gl061801

Talaat, E. R., Yee, J. H., and Zhu, X. (2001). Observations of the 6.5-day wave in the mesosphere and lower thermosphere. J. Geophys. Res.: Atmos., 106(D18), 20715-20723. https://doi.org/10.1029/2001JD900227

Talaat, E. R., Yee, J. H., and Zhu, X. (2002). The 6.5-day wave in the tropical stratosphere and mesosphere. J. Geophys. Res. :Atmos., 107(D12), 4133. https://doi.org/10.1029/2001JD000822

Tao, M. C., Konopka, P., Ploeger, F., Riese, M., Müller, R., and Volk, C. M. (2015). Impact of stratospheric major warmings and the quasi-biennial oscillation on the variability of stratospheric water vapor. Geophys. Res. Lett., 42(11), 4599-4607. https://doi.org/10.1002/2015gl064443

von Savigny, C., Robert, C., Bovensmann, H., Burrows, J. P., and Schwartz, M. (2007). Satellite observations of the quasi 5-day wave in noctilucent clouds and mesopause temperatures. Geophys. Res. Lett., 34(24), L24808. https://doi.org/10.1029/2007gl030987

Wallace, J. M., Panetta, R. L., and Estberg, J. (1993). Representation of the equatorial stratospheric quasi-biennial oscillation in EOF phase space. J. Atmos. Sci., 50(12), 1751-1762. https://doi.org/10.1175/15200469(1993)050<1751:ROTESQ>2.0.CO;2

Wang, J. Y., Yi, W., Chen, T. D., and Xue, X. H. (2020). Quasi-6-day waves in the mesosphere and lower thermosphere region and their possible coupling with the QBO and solar 27-day rotation. Earth Planet. Phys., 4(3), 285-295. https://doi.org/10.26464/epp2020024

Wu, D. L., Hays, P. B., and Skinner, W. R. (1994). Observations of the 5-day wave in the mesosphere and lower thermosphere. Geophys. Res. Lett., 21(24), 2733-2736. https://doi.org/10.1029/94GL02660

Xu, J. Y., Liu, H. L., Yuan, W., Smith, A. K., Roble, R. G., Mertens, C. J., Russell III, J. M., and Mlynczak, M. G. (2007). Mesopause structure from thermosphere, ionosphere, mesosphere, energetics, and dynamics (TIMED)/sounding of the atmosphere using broadband emission radiometry (SABER) observations. J. Geophys. Res.: Atmos., 112(D9), D09102. https://doi.org/10.1029/2006jd007711

Zawodny, J. M., and McCormick, M. P. (1991). Stratospheric aerosol and gas experiment II measurements of the quasi-biennial oscillations in ozone and nitrogen dioxide. J. Geophys. Res.: Atmos., 96(D5), 9371-9377. https://doi.org/10.1029/91JD00517

Zhang, X. L., Forbes, J. M., Hagan, M. E., Russell III, J. M., Palo, S. E., Mertens, C. J., and Mlynczak, M. G. (2006). Monthly tidal temperatures $20-120 \mathrm{~km}$ from TIMED/SABER. J. Geophys. Res.: Space Phys., 111(A10), A10S08. https://doi.org/10.1029/2005ja011504 